\title{
Disqualifications of Decisional Officials in Rulemaking
}

\author{
Peter L. Strauss*
}

What constraints on impartiality govern agency officials responsible for decisions in proceedings other than on-the-record adjudications? The past few years have witnessed the emergence of a striking body of professional debate, statute, and case law concerning ethics in government and the control of "special interest" influence on governmental decisions. Higher standards for conflict of interest, expanded constraints on ex parte communications, and enlarged concerns about separation of functions within the agencies are parts of this development. Another strand, tangled with the others yet doctrinally distinct, concerns the disqualification of responsible government officials for their prior contacts with or expressions of opinion on issues to be brought before them for decision. In the familiar setting of on-the-record adjudication, near-judicial impartiality is a conceded requisite. Today, arguments for disqualification are being pressed with vigor, and responded to, well beyond this setting. This paper is addressed to these developments.

\section{The Disqualification Problem}

Several recent cases illustrate the emerging controversies. The best known is Association of National Advertisers v. Federal Trade Commission (ANA), ${ }^{1}$ which arose in the course of rulemaking proposing constraints on television advertising directed at children. The rulemaking was to be conducted under the specialized rulemaking procedure of the Magnuson-Moss Warranty - Federal Trade Commission Improvement Act. ${ }^{2}$ Ordinarily, agency rulemaking requires only pub-

\footnotetext{
* Professor of Law, Columbia University. B.A. 1961, Harvard University; LL.B. 1964, Yale University.

This Article is based on a report submitted to the Administrative Conference of the United States in the spring of 1980. The study was provoked by a district court opinion, Association of Nat'l Advertisers v. FTC, 460 F. Supp. 996 (D.D.C. 1978), which on appeal became the occasion for one of the very last of Judge Leventhal's opinions, issued posthumously. Association of Nat'l Advertisers v. FTC, No. 79-1117 (D.C. Cir. Dec. 27, 1979), cert. denied, 100 S. Ct. 3011 (1980). The opinion, a concurrence, was marked by characteristic insight and grace, and reflected the judge's profound capacity to understand and accommodate the legitimate claims both of government agencies and of those subject to their regulation. Those who labor in this field will always remain deeply in his debt.

The views expressed in this Article are solely those of the author. They reflect his consultations with persons in and out of government, and have been much aided by the Conference's processes, but the responsibility for them nonetheless remains with him. Richard Andersen, Jeff Shapiro, and Kay Sherman of the class of 1981 provided valuable research assistance.

Masculine pronouns are used throughout this Article, in conformity with Review style; they should be understood to refer to women as well as men.

1. No. 79-1117 (D.C. Cir. Dec. 27, 1979), cert. denied, 100 S. Ct. 3011 (1980).

2. 15 U.S.C. $\$ 57 \mathrm{a}(1976)$.
} 
lished notice of a proposal, an opportunity for written public response, and subsequent publication of the rule together with a "concise general" explanation. Under the FTC procedures, however, disputed issues of material fact, once identified, are to be determined on the record using procedures including so much cross-examination as is appropriate and required for a full and true disclosure. ${ }^{3}$ Before the rulemaking had begun, but in apparent response to a petition for rulemaking filed by two "public interest" groups, Michael Pertschuk, the Commission's Chairman, made a number of statements reasonably taken as indicating strong views on the need and justification for regulating television advertising aimed at children. ${ }^{4}$ Later, the Commission's staff published an extensive Staff Report on Televised Advertising to Children, ${ }^{5}$ and the Commission announced the formal initiation of a rulemaking proceeding. It sought comment on remedial measures its staff had proposed and solicited further suggestions from other sources, identifying sixteen broad issues as particularly (but not exclusively) deserving of comment. ${ }^{6}$ These issues included matters about which Chairman Pertschuk had previously expressed strong opinions-for example, whether children younger than a certain age would ordinarily understand the commercial purpose of advertising or whether the consumption of sugared products at or between mealtimes contributes to tooth decay. Shortly after the notice was published, and thus before "disputed issues of material fact," if any, could be identified, ${ }^{7}$ the Association of National Advertisers sought Chairman Pertschuk's disqualification from further participation in the proceeding because he had allegedly prejudged the matters to be determined. Replying that he held only "tentative views on policy issues or legislative facts," the Chairman declined to remove himself from the proceeding. He was upheld in this by the Commission ${ }^{8}$

3. These procedures have been the subject of recent intense study and a report, including recommendations, to Congress by the Administrative Conference. See ACUS Recommendation 79-1, 44 Fed. Reg. 38,817 (1979). The study did not reach disqualification issues. The Commission's efforts to regulate television advertising to children, although never yet brought near the point of effective action, have already been the subject of considerable dispute. E.g., Matter of ITT Continental Baking Co., 82 F.T.C. 1183 (1973); Association of Nat'l Advertisers v. FTC, 617 F.2d 611 (D.C. Cir. 1979). Legislative controls are also under active consideration.

4. For example, he appeared before one of the groups that had submitted the rulemaking petition to discuss the legal theories and tactics by which controls over advertising to children could be achieved. He wrote the Administrator of the Food and Drug Administration of his "conviction that one of the evils flowing from the unfairness of children's advertising is the resulting distortion of children's perceptions of nutritional values," and went on to explain the tactics of securing a readily defended rule to curb the "commercial exploitation of children," particularly with respect to the sale of sugared products.

5. The Report was made public on Feb. 5, 1978, and discussed in a public meeting of the Commission on Feb. 28, 1978.

6. 43 Fed. Reg. 17,967 (1978).

7. In a separate part of its action, the Commission had set time limits for submission of written comments and provided for the holding of an informal, "legislative" hearing; at the conclusion of that hearing, the Commission indicated, it would decide whether "crucial issues" of disputed fact remained that required a form of on-the-record determination (possibly including cross-examination). See 43 Fed. Reg. 17,967 (1978). These procedural arrangements, on the whole consistent with the Administrative Conference's subsequent recommendations, note 3 supra, have been cast into some doubt by dicta in the majority opinion in Association of Nat'l Advertisers v. FTC, 617 F.2d 611 (D.C. Cir. 1979).

8. TRR No. 215-60, July 18, 1978. 
and, after a reversal in district court, ${ }^{9}$ by a divided panel in the Court of Appeals for the District of Columbia Circuit. ${ }^{10}$

In a second case, Chairman Daniel O'Neal of the Interstate Commerce Commission was challenged by truckers anxious to prevent his participation in a rulemaking pointing toward deregulation of the trucking industry. In speeches and other statements the Chairman had indicated that he favored deregulation, and this the truckers urged was disqualifying. Here only notice and comment procedures were being employed; a factual as distinct from policy component in the Chairman's statements was hard to identify; and his comments were generally milder and more guarded than those of Chairman Pertschuk. When Chairman O'Neal declined to disqualify himself, the truckers unsuccessfully sought injunctive and declaratory relief in federal district court. ${ }^{11}$

In a third case, Carol Foreman, an Assistant Secretary of Agriculture, was participating in an informal rulemaking proceeding concerned with the proper method for marking the net weight of retail meats. She had made some remarks suggestive of a point of view in the rulemaking while addressing a consumer group convention. She had also been closely connected with the award of a contract to conduct research possibly bearing on the rulemaking - and the contractor was the private organization from which she had come to the government. For these and related reasons, she was alleged to be carrying forward the private interests of her previous employer and hence to be an improper decisionmaker in a public proceeding; disqualification was refused, largely on prematurity grounds. ${ }^{12}$

Finally, a controversy arose when Dr. Eula Bingham, Administrator of the Occupational Safety and Health Administration (OSHA), gave a speech to one group highly interested in the outcome of a rulemaking, after the public comment period had closed but about two weeks before publication of the rule in final form. She indicated firm views on several strongly contested issues, described her forceful political efforts within the government to obtain a rule, and invited her listeners' political support for the incumbent administration in forthcoming elections. ${ }^{13}$ The rulemaking was conducted in hybrid fashion with

9. Association of Nat'l Advertisers v. FTC, 460 F. Supp. 996 (D.D.C. 1978).

10. No. $79-1117$ (D.C. Cir. Dec. 27, 1979), cert denied, 100 S. Ct. 3011 (1980).

11. Assure Competitive Transp., Inc. v. ICC, 45 Ad. L.2d 1134 (D.D.C. 1979).

12. Grocery Mfrs. of America v. Foreman, Civ. No. 78-2245 (D.D.C. Dec. 27, 1978), appeal pending, No. 79-1440 (D.C. Cir.).

13. The following passages, excerpted in the petitioner's brief, convey the flavor and range. Brothers and Sisters...

Now I want to tell you that we are going to have a Lead Standard. I am determined, Secretary Marshall is determined, and I'm convinced that the President is committed. I can tell you that Secretary Marshall and I have been through the palace guard once to see him about a standard, and if we have to go through that palace guard again, we shall....

I think that there may be some apprehension because Assistant Secretaries in the past have not always understood, or have not known how to spell the words medical removal protection, or rate retention, or whatever the word is that you choose to use. Well, I learned to spell those words a long time ago on the Coke Oven Advisory Com- 
cross-examination permitted as to "crucial issues"; ${ }^{14}$ it is to be reviewed on the basis of a "substantial evidence" standard. The lead industry unsuccessfully argued to the D.C. Circuit that the Administrator's address reflected disqualifying bias that invalidated the outcome. ${ }^{15}$

Taken together, these cases suggest both an upwelling of controversy about disqualification issues in informal proceedings, notably rulemakings, ${ }^{16}$ and a range of possibly determinative variables bearing on the controversy. All those seeking disqualification have begun with the more or less familiar judicial analogy. The responses of the administrators concerned in refusing to disqualify themselves have in part been to assert that no judge in like circumstances would be compromised. But they have also stressed that other factors make the judicial analogy inapposite for rulemakings.

One such factor is suggested by the significant structural differences between rulemaking and adjudication. Rulemaking typically requires the rulemaker to formulate proposals. That responsibility suggests a general duty to acquire expertise and perspective regarding the setting in which the rulemaker is to act; and a specific need to reach the prejudgments necessary for making a particular proposal and choosing preliminarily among possible formulations of it. Choosing cases for prosecution is often separated from deciding those cases; but the function of proposal formulation could not comfortably be separated from the function of rulemaking itself. The decision how effort is to be allocated in policymaking is indistinguishable from policymaking, and must be lodged at the

mittee, and if you want to know how I feel about it, you need only to look up my comments during those Committee Hearings. As far as I'm concerned, it is impossible to have a Lead Standard without [rate retention] .... .

I have told some people that I have never aspired to be an economist, but I tell you I can smell a phony issue when I see one. And to say that safety and health regulations are inflationary is phony ....

Between now and next Tuesday (election day), I'm gonna ask that each of you in this room do a couple of things. First of all, look at the people who are running in your state, in your congressional district. And look at those people and see which ones care about people and working men and women. These individuals can make a big difference in your lives, and you know it. I can tell you right now that a big difference will be made if a Dr. Roy is elected in Kansas, and some of our people are returned to Congress, such as Martha Keyes in Kansas, and a Bob Krueger in Texas, would make a big difference. And that's what I'm really asking you to do is go out and do what you can between now and Tuesday to make a big difference to us all. will.

And I'll do my job, and I don't know how you're gonna help me, but I'm sure you

Consolidated Brief of Industry Petitioners and Intervenors at 25-27, United Steelworkers of America v. Marshall, No. 79-1048 (D.C. Cir., filed Aug. 15, 1980).

14. 29 C.F.R. § 1911.15(a)(3) (1979), implementing § 6(b) of the Occupational Safety \& Health Act, 29 U.S.C. $\$ 655$ (1976).

15. United Steelworkers of America v. Marshall, No. 79-1048, slip op. at 17-23 (D.C. Cir. Aug. 15, 1980).

16. This Article has been written with informal rulemaking principally in view. Many of its observations, however, could also be made respecting forms of on-the-record adjudication that are strongly policy oriented in character, most notably initial licensing. Separation of functions is not required under the APA in on-the-record licensing proceedings, 5 U.S.C. $§ 554$ (d) (1976), suggesting lesser scope for disqualification in these proceedings as well. 
center. ${ }^{17}$ It follows that the discussions and judgments antecedent to a proposal for rulemaking cannot, by the simple fact of their occurrence, disqualify. That is not to say that tentativeness in reaching these judgments is unimportant; or that a demonstration of unshakeable prejudgment might not be thought the occasion for disqualification. But if some measure of prejudgment is essential or inevitable in the preliminary stages of rulemaking, to that extent at least disqualification is foreclosed.

Similarly, in the current state of law, rulemaking is regarded as an appropriately institutional, not individual, decision. A result is that to the extent disqualification is a concern at all, it may be a concern for a larger and less certain number of agency employees than would be thought implicated in adjudication. Even when required to act "on the record," a commissioner is unconstrained by statutory or constitutional separation of functions requirements in rulemakings. The sifting and analysis by competent subordinates, which would in any case be permitted, ${ }^{18}$ need not exclude staff members who participated in formulation of the rule and presentation of information bearing on it. ${ }^{19}$ More important, significant aspects of decision are likely to have been given effective final shape below the highest levels of the agency. ${ }^{20}$ Consequently, the field of agency personnel ultimately identified as decisionmakers may be much larger than would be the case for on-the-record adjudication. In an adjudication, it is not hard to identify those who reach the holding of an opinion, and perhaps the few who help to write any explanation; in rulemaking, the decision lies in a text whose formulation can involve a sizeable proportion of an agency's management-level staff. That disqualification rules would have to reach so broadly is an additional consideration constraining simple application of the judicial model.

Rulemaking can also be differentiated from adjudication on the basis of the differing relationships of those two procedural forms to other roles that adminis-

17. This point is central to the prevailing opinions in the $A N A$ case, slip op. at $20,33-38$ (Tamm, J.); id. at 4 (Leventhal, J., concurring). Compare the requirement in Exec. Order No. 12,044, 43 Fed. Reg. 12,661 (1978), for semiannual publication by agencies of their rulemaking agendas. The basic thrust of that order, and of much thinking about rulemaking endeavors today, is to insist on increasing involvement in and responsibility for rulemaking at the top. Such changes can be effected only at the cost of enhanced "prejudgment."

18. Morgan v. United States, 298 U.S. 468 (1936).

19. See, e.g., Hoffman-La Roche, Inc. v. Kleindienst, 478 F.2d 1 (3d Cir. 1973); American Tel. \& Tel. Co. v. FCC, 449 F.2d 439 (2d Cir. 1971); Willapoint Oysters, Inc. v. Ewing, 174 F.2d 676 (9th Cir.), cert. denied, 338 U.S. 860 (1949). As is pointed out in an NRC draft report, A Study of the Separation of Functions and Ex Parte Rules in Nuclear Regulatory Commission Adjudications for Domestic Licensing 123-28 (1980), the recent decision in Home Box Office, Inc. v. FCC, 567 F.2d 9 (D.C. Cir.), cert. denied, 434 U.S. 829 (1977), has placed this proposition in some doubt for the future.

Section 12 of the Federal Trade Commission Improvements Act of 1980, Pub. L. No. 96-252, 94 Stat. 374 (1980), added a new section $18(f)$ to the Federal Trade Commission Act, 15 U.S.C. $\S$ $15 \mathrm{a}(\mathrm{k})$, specifically imposing separation of functions requirements as to "any fact which is relevant to the merits of such proceeding and which is not on the rulemaking record of such proceeding, unless such communication is made available to the public and is included in the rulemaking record. $"$

20. See, e.g., Pedersen, Formal Records and lnformal Rulemaking, 85 Yale L.J. 38 (1975); National Nutritional Foods Ass'n v. FDA, 491 F.2d 1141, 1145-46 (2d Cir.), cert. denied, 419 U.S. 874 (1974). 
trators are called on to perform. Decision in an individual case, at least as distinct from its policy or rule component, is of limited institutional concern to Congress, the President, or those generally affected or protected by regulation. Our political and legal traditions exclude the calling of judges before legislative committees to explain their decisions, the clearing of proposed decisions with the President, and nonparty intervention. ${ }^{21}$ But we have no such traditions for policymaking divorced from the decision of particular cases. Congressional oversight of administrative policymaking is generally regarded as a good, and current trends are to increase it; so also for Presidential controls. While dispute has very recently arisen over whether these controls must be publicly exercised, the legitimacy of the controls themselves is generally conceded.

Similar differences characterize administrative relations with interested parties outside government. Businessmen who have no need for hints how a particular case will be decided have a legitimate and pressing concern to learn "the drift of current policy thinking and planning'" at relevant agencies, so that they may shape their own activities. The hope that businessmen will shape those activities toward compliance, or that knowledge of the emerging thought will provoke them into providing information permitting more effective regulation, warrants the agency's personnel in giving the hints and even in seeking out opportunities in which to do so. More diffuse public groups, too, have a claim to hear and be heard on questions concerning the agency's course. Again, there may be questions whether the interchanges - at the least, those clearly pointed toward a particular rulemaking - need to be public; but their value is generally recognized. Disqualification rules need to be consistent with the occurrence of these events. If attending convention lunches and speaking to "issues of the day" is a legitimate part of a rulemaker's function, he ought not be disqualified merely for having done so.

Related to this proposition is the appropriately political character of appointment to positions of responsibility at the top of the administrative hierarchy. While judges, too, may in part be selected for their political leanings, no sense of apology attends that principle of selection in the administrative sphere. Unlike judges, administrators have a fixed program to carry out, and their success or failure is measured by their ability to achieve politically defined policy ends. If policy commitment is a measure of sound appointment, it would be surprising to find it disabling.

Another frequently distinguishing characteristic of rulemaking concerns the nonspecific character that often attaches to factual controversies. To be sure, rulemaking spans a notoriously diverse set of procedures and contexts, from formal, on-the-record rate-setting premised on ascertainable and historical facts

21. Nonparties may appear, of course, as amici curiae-generally helping the court assess the possible sweep of a given result more than helping it decide the particular case. In general, amici are not invited, and their participation is permissive. Amici appearances are not a central feature of judicial decision; they reflect an accommodation to our recognition that judicial decisions sometimes have broad policy consequences for which judicial decisions on the usual model may prove inadequate. From this perspective, the need for amici in a given case calls into question more than it reinforces such other elements of the traditional model as independence from the political branches. 
about particular corporations to informal standard-setting based substantially on political attitude or on feel for future developments. Rulemaking may produce standards of general impact on large parts of society, or have the effect of resolving particular disputes affecting discrete parties with specific interests unusually at stake. Generalization is therefore fraught with hazard. There is nonetheless agreement that factual disputes in rulemaking most frequently concern issues that, if decided by a court at all, are decided under the rubric of judicial notice rather than trial. "Are children manipulated by television advertisements?" more closely resembles "Are children disadvantaged by segregated education?" than "Was Jones fired for reasons of race?" The questions may be susceptible of definitive answer or engender great controversy, but there would be no constitutional objection to having them decided by a legislature using the most informal procedures; the basis for Jones's discharge, a question unique to the case in which it arises, cannot be so decided against Jones's interest.

Finally, in considering the question of disqualification one must take into account the high current levels of controversy over appropriate rulemaking procedures generally. As a matter of description, the differences in structure, institutional character of decision, relationship to other agency roles and actors, and general nature of facts to be determined, all would probably be agreed upon as distinguishing rulemaking from adjudication. Nonetheless, current scholarship and judicial decisions reflect disquiet about rulemaking as traditionally understood. ${ }^{22}$ The disqualification issue is touched by these controversies, particularly by such questions as the extension of "ex parte" concepts to rulemaking, ${ }^{23}$ the protection of rulemaking from Presidential or congressional influence or pressure, ${ }^{24}$ and the extension to rulemaking of separation of functions constraints currently prescribed by statute only for formal adjudication. ${ }^{25}$ Each of these controversies could be said to involve, in a general way, the disputants' estimate of the importance of "impartiality" or "objectivity" in rulemaking. Is this a political activity integral to the daily functioning of the agency as a whole and so subject to all the influences that may come to bear on that functioning? Or is it, and if so to what degree and in what circumstances, to be dissociated from the political, from the hurly-burly, and conducted antiseptically? The former view produces a model of administrators who approximate congressmen, and thus discourages disqualification; the latter suggests the setting for judicial activity and so encourages the importation of judicial standards.

22. The controversies are well analyzed in DeLong, Informal Rulemaking and the Integration of Law and Policy, 65 Va. L. Rev. 257 (1979).

23. Nathanson, Report to the Select Committee on Ex Parte Communications in Informal Rulemaking Proceedings, 30 Ad. L. Rev. 377 (1978); ACUS Recommendation 77-3, 1 C.F.R. § 305.77-3 (1980).

24. The Conference has currently pending a study of this problem by Dean Paul Verkuil, see page 943 supra.

25. The Conference has currently pending a study of this problem by Professor Michael Asimow. See Ross, ABA Legislative Proposals to Improve Administrative Procedures in Federal Departments and Agencies, 27 Ad. L. Rev. 395 (1975); Davis, Revising the Administrative Procedure Act, 29 Ad. L. Rev. 35, $42-43$ (1977); Pedersen, The Decline of Separation of Functions in Regulatory Agencies, 64 Va. L. Rev. 991 (1978). 
How, then, are we to proceed? The following pages begin at the outer limits of analogy, where general agreement exists respecting the constraints appropriate for the analogous procedures, and then work toward the center. The first limit examined is suggested by the conflict of interest rules prohibiting legislators and executive officials from participating in certain decisions. If particular conflicts of interest would or should be regarded as disqualifying even in a legislator or executive official, it is supposed here that they should be disqualifying for a rulemaker, however political we may regard his function to be. An examination of current trends in thinking about conflicts of interest and the reduced political controls over most rulemakers may suggest additional measures beyond those appropriate for an elected legislator or executive. The second limit examined, the one most frequently reasoned from in the cases, consists of the disqualification rules applicable to judges (and, by derivation, administrators acting as judges). If some relationships to parties, facts, or issues would not be treated as disqualifying even in a judge, the rulemaker can hardly be disabled. In particular, if judges are not disqualified for their prior exposure to social fact or their political or policy views, rulemakers are by hypothesis similarly free, whatever restraints are placed on the way in which they acquire, process, and use information. Indeed, given the more focused policy responsibilities of administrators and the political considerations that, legitimately, so often underlie their appointment, disqualification for policy views would be astonishing.

\section{Constraints on Politicians: The Conflict of Interest Model}

\section{A. Congressional, Executive, and Professional Disqualification}

If one searches outside the administrative and judicial realms for indications of conduct or associations regarded as disqualifying from participation in government action, one finds broad agreement that personal financial interests are disqualifying, and little else. Thus, the provisions of the United States Code dealing with bribery, graft, and conflicts of interests ${ }^{26}$ prohibit paying (or receiving payment) for the assistance of governmental officials at all levels, and prohibit government employees from personal and substantial participation in a " particular matter in which, to his knowledge, he, his spouse, minor child, partner, organization in which he is serving ... or any person or organization with whom he is negotiating or has any arrangement concerning prospective employment, has a financial interest." ${ }_{27}$ The limitation of disqualification to present,

26. 18 U.S.C. ch. 11 (1976).

27. 18 U.S.C. $\S 208$ (1976). Section 208 applies only to executive branch, independent agency, or District of Columbia employees, but like constraints govern the judiciary and the legislative branch. See, e.g., Senate Manual, S. Doc. No. 1, 95th Cong., 1st Sess. Sen. rule XLV, § 8 (1977).

Although the reference to "particular matter" could be taken to exclude the application even of this limited provision to rulemaking, $\S 208$ is generally understood to apply to rulemaking as well as adjudication or contract or grant activities. Other sections in Chapter 11, notably 18 U.S.C. § 207, treating the disqualification of former officers and employees, refer to "particular matter involving a specific party or parties." The absence of the "specific party or parties" qualification in $\S 208$ is generally taken to signal its application to rulemaking. S. Rep. No. 170, 95th Cong., 1st Sess. 48 (1977). A view that the reference to "a specific party or parties" was not intended to suggest any 
financial interests is striking; not only is no disqualification imposed where the specified ties have been broken, but a Nuclear Regulatory Commission employee may remain an officer of the Sierra Club or the Business Roundtable, or seek employment with the Union of Concerned Scientists, without violating the Act. ${ }^{28}$

The rules of both houses of the Congress make similarly limited judgments about disqualification. A member who has a "direct personal or pecuniary interest" is excused from voting-but the rules stress the need for a uniquely personal impact. Thus, members of the House who held New York State or City bonds were not disqualified to vote on a measure authorizing emergency guarantees of state obligations; their possible interest in the outcome was broadly shared in the community at large. ${ }^{29}$ Senate conflict of interest rules on voting apply only to legislation principally aimed at furthering the pecuniary interest of the Senator personally, his family, or a limited class of persons to which he belongs. Employees of Senate committees are directed only to divest themselves of any substantial holdings that may be "directly affected by the actions of the committee" for which they work, and that only if they earn more than $\$ 25,000$ annually and work more than ninety days. ${ }^{30}$ Other than financial disclosure rules, criminal restraints on bribery, and occasional sensitivity about focused serving of self-interest, few limits are imposed on a congressman's use of his considerable authority.

Recent events provoking public interest in the probity of governmental officials, most notably the Watergate scandal, have prompted fresh examinations of the conflict of interest problem. The resulting new standards, however, fit the established pattern; they have been almost entirely limited to issues of financial self-interest. The Ethics in Government Act of $1978^{31}$ provides intimately for the filing of reports about financial interests and institutional responsibilities, and creates a new bureaucratic mechanism to administer federal conflict of interest standards, but makes essentially no change in the legislative statement of those standards. As distinct from continuing personal or financial interests, the knowledge or attitudes an individual brings to government still are not an apparent matter for ethical or oversight concern. ${ }^{32}$

difference between the sections is expressed in Jordan, Ethical Issues Arising from Present or Past Government Service, in ABA, Professional Responsibility 177 n.21 (1978). In Mr. Jordan's view, however, neither $\$ 207$ nor $\S 208$ applies to general rulemaking.

28. Agency and judicial practice has occasionally been more demanding. Thus, the Internal Revenue Service has regarded religious scruples as disqualifying individuals from participating in determining the exempt status of an organization involved in abortion. And a commissioner of the Equal Employment Opportunity Commission was held to have erred in participating in an agency rulemaking, where she was considering taking a nonpaying position with a women's rights organization that had declared its stand on the issue she was to vote upon. Air Transp. Ass'n v. Hernandez, 264 F. Supp. 227 (D.D.C. 1967)

29. See H.R. Doc. No. 403, 95th Cong., 2d Sess. 313 (1979) (rule VIII); 121 Cong. Rec. 38,135 (1975); see also $A N A$, slip op. at $28 \mathrm{n} .9$ (MacKinnon, J., dissenting in part and concurring in part).

30. Senate Manual, S. Doc. No. 1, 95th Cong., 1st Sess., rule XLV, $§ 8$ (1977) (effective April 1, 1978).

31. Pub. L. No. 95-521, 92 Stat. 1824 (1978) (codified in part at 5 U.S.C. App.).

32. In its provisions governing the conduct of former employees after leaving government service, the Ethics in Government Act is principally limited to matters "involving a specific party or parties," not rulemaking. Participation in rulemaking activities is affected only by new 18 U.S.C. $\S$ 
Contemporary standards of the legal profession also suggest few occasions for disqualification in legislative or policy making activities (as distinct from matters involving "a particular party or parties"), although a trend toward recognizing a need for disqualification may exist. Thus, disciplinary rule 9-101(B) of the Code of Professional Responsibility states that "A lawyer shall not accept private employment in a matter in which he had substantial responsibility while he was a government employee," but the current ABA interpretation of this phrase excludes rulemaking:

[W]ork as a government employee in drafting, enforcing, or interpreting government ... regulations ... does not disqualify the lawyer under D.R. 9-101(B) from subsequent private employment involving the same regulations .. .; the same "matter' is not involved because there is lacking the discrete, identifiable transactions or conduct involving a particular situation and specific parties. ${ }^{33}$

This reading, which has been strongly criticized, ${ }^{34}$ does not obviate the possibility that a lawyer would be disqualified for a different reason-that a particular controversy might require or appear to require him to violate the confidences of his former (government) client, contrary to canon 4 of the Code of Professional Responsibility. As now written, the Code imposes no explicit disqualification on the government lawyer who comes from private practice, beyond the obligation to preserve a former client's confidences. ${ }^{35}$

207(c), which applies to former holders of significant decisionmaking or supervisory responsibilities - at least the GS-17 level-and prohibits for one year their personal efforts to influence determinations of or substantially affecting their former agencies. The obvious concern of this provision, which applies to all matters before or affecting the agency, is with misuse of the influence or friendships acquired in a former position of authority. A matter need have been neither pending nor included within the former civil servant's responsibility or personal work docket to fall within the ban of $\S 207$ (c). At the end of a year, $\S 207$ (c)'s prohibition on advocacy ceases; and during that year the former civil servant may freely advise new colleagues respecting their own appearances.

33. ABA Formal Op. No. 342, 62 A.B.A.J. 517, 519 (1976).

34. Association of the Bar of the City of New York, Committee on Professional and Judicial Ethics, Op. No. 889, 31 The Record 552, 557-58 (1976); Jordan, supra note 27, at 194-97. The criticisms nonetheless recognize the practical difficulties inherent in an approach that might seem to bar a former Commissioner of Internal Revenue, say, from future tax consultations for any client, and apparently would accept the District of Columbia Bar proposal discussed in note 35 infra as an appropriate means for dealing with the problem.

35. This obligation is routinely observed by government attorneys, who may give standard instructions that they are not to be consulted on matters particularly concerning the interests of a former client. Typically, although not invariably, these instructions are limited to "particular matters", (i.e., adjudications, rulings, etc.) in which a former client or law firm is involved, and government lawyers do not refrain from participation in rulemaking because they learned facts in private practice possibly bearing on the outcome. Disqualifying oneself from a rulemaking in which a lawyer or his firm has been an active participant or (particularly) initiator appears to be regarded as the better practice by those agencies considering the matter.

Recent proposals by the Board of Governors of the District of Columbia Bar, made after long and intensive debate, would impose certain disqualifications respecting rulemaking, but are strikingly limited in their application to general policymaking activities. Final Report of the Legal Ethics Committee, 3 Dist. L. 44 (Aug.-Sept. 1978). Although new public employees would have to disqualify themselves permanently from any "matter' in which they "participated personally and substantially while in private practice or employment," and for one year from "matters" involving recent former clients or law associates, the proposal established no explicit restriction on an entering government 


\section{B. Conflict of Interest Disqualification in Agency Rulemaking}

1. Current Practice. The current regime for conflict of interest regulation in the civil service owes its shape to Executive Order 11,222 , promulgated during the Johnson administration, and the implementing Office of Personnel Management regulations. ${ }^{36}$ Under these rules, all federal agencies are obliged to have in place regulations governing employee responsibilities and conduct. These regulations are generally understood to be concerned with conflicts of interest as distinct from prejudgment as such. They set out in rich detail the financial holdings and outside employment permissible for government employees and (as to the first) their immediate families; to enforce these constraints, high level employees file annual reports for review by agency counsellors. Originally confidential, the reports of senior employees are now available to the public, under the Ethics in Government Act. ${ }^{37}$ On the basis of the reports, and following procedures provided for in varying detail, apparent conflicts are identified and remedies, including disqualifications, are worked out.

Some universal characteristics may be listed, few surprising and most reflecting the criminal provisions already discussed. An employee may not participate in a matter in which he or an immediate family member holds a financial interest, unless by rule or special determination the interest has been found so slight as to be waivable. He may not participate in a matter involving one with whom he is negotiating for possible future employment or accept outside employment that could cause conflicts with his government position. The procedures provided for enforcing these constraints are internal, arising either from the employee's identification of a problem or from the process of reviewing the annual statements. The rules are designed to pick up financial interests and associational interests of a commercial or financial character. Political, religious, or civic associations need not be reported; activities on behalf of such organizations are outside the "other employment" constraints. Neither the Executive Order model nor the rules of most agencies deal with possible conflicts arising out of prior employment, or provide for a "cooling off" period during the first years of government service.

In responding to an Administrative Conference inquiry in connection with this study, agencies generally agreed that conflict of interest rules, in the usual limited sense connoting present financial or associational conflicts, apply in rulemaking as in other forms of agency action. The statutory provisions and the

counsel's participation in rulemaking of general applicability. For counsel leaving government office, it proposed a five-year moratorium on counselling or representation with respect to the adoption or validity of any rule which counsel participated "personally and substantially" in drafting, proposing, or adopting. See generally Opinions 71 and 78 of Committee on Legal Ethics of the District of Columbia Bar (June 26 \& Nov. 20, 1979). Even were the broader prohibitions on participation in "matters" thought to apply, these prohibitions stem from client relationships and work associations, not prior opportunity to acquire knowledge or formulate views that might be relevant to the proposals under examination. On April 17, 1980, the D.C. Court of Appeals issued proposed rules that did not include these proposals. Legal Times of Wash., Apr. 28, 1980, at 8.

36. 3 C.F.R. $\$ 130$ (Supp. 1965); 5 C.F.R. $\$ \$ 735.201-735.210,735.401-735.412$ (1980).

37. 5 U.S.C. App. (Supp. II 1978); implementing OPM regulations are at 5 C.F.R. $\$ \$$ $735.501-735.508$ (1980). 
Executive Order can be read to take in all forms of governmental action; the public would expect its servants to be free of self-serving in policymaking contexts as much as in other forms of administration. There would seem, then, little reason to pause over applying core conflict of interest precepts to rulemaking activity.

Nonetheless, a very few agencies appear to regard the provisions for disqualification from particular matters as not reaching general rulemaking. ${ }^{38}$ Other agencies treat any possible concern as answered by the increasingly common flat prohibitions on any ownership of stock in regulated companies. Although the flat prohibitions present the most egregious conflicts, policymaking of a general character may well have significant, but often hard to anticipate, effects on a broader range of financial interests - and the prohibitions divert attention from these effects. Thus, an employee of the Food and Drug Administration (FDA) is much more likely to understand and accept that he cannot own stock in Warner-Lambert, a regulated producer of veterinary medicine, than that his ownership of part interest in an unregulated beef feed lot precludes participation in a general rulemaking concerning quality standards for animal food additives.

As a technical matter, the conflict of interest provisions do apply to this situation. The Department of Justice, in response to an FDA inquiry, was clear that 18 U.S.C. $\S 208$ (a) would reach an investor in feedlot operations who participated in an advisory committee's deliberations about continued use of antibiotics in animal feed to avoid illness and promote growth; the section "applies to any discrete or identifiable decision or recommendation, or other matter even though its outcome may have a rather broad impact. . . . A benefit conferred on an industry generally can be as much of a boon to a firm within that industry as a competitor's going out of business." ${ }^{39}$ As the Department noted, the statute provides a mechanism for dealing with de minimis situations-published waiver either in the individual case or by general rule if it can be concluded that a given interest could not affect the integrity of employee services in any context. And, it thought, disqualification could not be imposed for an outcome that affected the firm "merely as a member of the general public or as part of the entire business community."

Yet not inconsiderable arguments favor the more limited approach of simply banning holdings in regulated industries. To put employees at peril of anticipating the side effects of rules, or even of knowing the roster of those volunteering at various times their comments in a rulemaking, is to impose a greater burden than that of staying aware of the parties in a discrete proceeding; and is to impose that burden without substantial gains for effective government as a

38. E.g., 10 C.F.R. § 1010.302(a)(1)(ii) (1979) ("particular matter" defined to exclude rulemaking) (Dep't of Energy); 39 C.F.R. § 3000.735-302(c)(2) (1979) (same; Postal Rate Comm'n); 17 C.F.R. \& 200.60 (1979) (SEC). The regulations of the Department of Transportation, unusually full in this respect, state that the test of an "other particular matter" is whether the employee's participation "will have a direct and predictable effect on the financial interest referred to . . .."

"[T]he words ... do not necessarily include rule making of wide applicability, the formulation of general policy or standards, or similar matters of broad scope." 49 C.F.R. $§ 99.735-15$ (c) (1979).

39. Letter from Ass't Att ${ }^{\prime} y$ Gen. John Harmon to Richard Cooper, Chief Counsel, FDA, dated June 29,1978 , at 4,8 . 
balancing factor. In general rulemaking, the very fact that impacts are diffuse and often unpredictable suggests less need to guard against their warping influence. The diffuseness also means that disqualification would produce greater inhibitions on employee investment - a freedom significant to them. Finally, what rises above a de minimis level for concern in this setting - an interest to be compared with, say, the consumer interest in food prices and quality - is hard to identify from the public's perspective.

The area of possible dispute here could be reframed in policy terms: would it be appropriate for an agency to provide by rule that employee investments likely to be affected by, but not directly subject to or benefiting from proposed regulation, are deemed insufficiently substantial to affect the integrity of employee services? ${ }^{40}$ If the risk of unseemliness in such a rule is excessive, might the agency set a relatively high level of total investment, beneath which the risk is regarded as de minimis? An agency might, for example, subject an employee to disqualification in rulemaking only if his investments were (a) in a corporation to be subject to the proposed rule or its immediate beneficiary, or (b) in a corporation likely to be affected by the regulation in a manner substantially distinct from the public or business community at large and exceeded $\$ 25,000$ in value. Unless we are at the point of limiting government employee investments to general mutual funds and like ventures, some such accommodation seems required; that accommodation would be entirely consistent with-indeed more demanding than - constraints currently observed in Congress and among its staff, and apparent general practice.

2. "Cooling Off" Periods? Conflict of interest disqualification is generally limited to present conflicts, making no provision for the impact of prior associations once ended. Section 207 of the Criminal Code, as amended by section 501 of the Ethics in Government Act, provides for certain post-employment restrictions; the more stringent of these apply only to "particular matter[s] involving a specific party or parties" - not general rulemaking - but high level employees are forbidden to seek to influence any matter before their former agencies, including rulemaking, for one year after leaving government office. ${ }^{41}$ No similar constraint exists on dealing with the interests of former employers while a government employee.

Specific instances of such constraints do exist. Under the Department of Energy's (DOE) reorganization legislation, former employees of "energy concerns" may not participate at a supervisory level for one year after leaving that employment, in a proceeding other than general rulemaking in which their former employer is interested. If an employee was substantially involved in or responsible for an energy concern's participation in a proceeding, whatever its character, during the five years before joining the Department, he may not participate in that proceeding for one year after joining. ${ }^{42}$ The Civil Aeronautics Board $(\mathrm{CAB})^{43}$ by rule and the Federal Communications Commission (FCC),

40. Compare the Department of Transportation rule, supra note 38.

41. 18 U.S.C. \& 207(c) (Supp. II 1978).

42. 42 U.S.C. $\$ \$ 7212,7216$ (Supp. II 1978); 10 C.F.R. $\$ \$ 1010.302(b), 304(b)$ (1979).

43. 14 C.F.R. \& 300.9-. 10 (1979). 
the Internal Revenue Service (IRS), and doubtless other agencies by practice impose similar restraints. Guidelines adopted by the incoming Carter administration for political appointees called for recusal from particular matters in which a recent prior employer had a substantial financial interest. ${ }^{44}$ And for attorneys, as earlier discussed, the rules of professional conduct prohibit participation in "matters" on which an attorney has worked for a former client, without time limit.

Provision at least for a cooling off period, and perhaps for permanent disqualification where an employee's contact with rulemaking in private employment had been personal and substantial, would be consistent with the current trend toward increasing separation between private and public employment, and could help allay suspicions about the "revolving door." 45 As a general matter, one must recognize that any such change occurs at the costs of depriving government of some - or possibly all-assistance by qualified and involved persons, of making government employment marginally less attractive (threatening to that extent the quality of the civil service), and of making personnel administration marginally more expensive - as the complexities of determining who works on what issues and the number of occasions on which relevant expertise must be sacrificed both increase. ${ }^{46}$

For analytic purposes, it may be useful to separate the question of a cooling off period from that of permanent disqualification. The latter measure is obviously more severe; it is not imposed by statute on any persons entering federal service, and for the legal profession and post-government employment such restraints are clearly limited to particular matters involving a specific party or parties in which the employee has substantially and personally participated. These limitations reflect policy considerations of major importance. Disqualification from one or several "particular matters involving a specific party or parties," as a government employee or after government employment, reaches the heart of concerns respecting conflict of interest, yet imposes only limited, manageable inhibitions on present government service or future private career. The range of disqualification is discrete, and suggests no disability to deal with political issues - only particular disputes. One is unlikely to be dissuaded from entering government service or discouraged from leaving it by these limited constraints, and the government as employer is not denied all use of the employee's experience and views. Such disqualification addresses the setting that marries the

44. Ethics Statements, 35 Cong. Q. Wkly. Rep. 56 (Jan. 8, 1977).

45. In discussing cooling off periods, we are addressing the employee who has completely and finally severed his connection to his prior employment; should there be an expectation of return, the employee is in a situation of present, actual conflict.

46. The difficulties of assessing these costs and the cautionary implications to be drawn from them are well illustrated in Professor Morgan's recent study for the Conference, Appropriate Limits on Participation in Matters Before an Agency by a Former Agency Official, (Exposure Draft) (1979), leading to ACUS Recommendation 79-7, 45 Fed. Reg. 2309 (1980) (to be codified in 1 C.F.R. 305.79-7). Although the Conference had no occasion to endorse Prof. Morgan's sharply skeptical questioning of the empirical base for post-employment restrictions or his observation that analogous restrictions arising from pre-employment activities should be observed, the tone of the recommendation suggests basic agreement with him. See also R. Vaughn, Conflict-of-Interest Regulation in the Federal Executive Branch (1979). 
greatest risk of conflicted loyalties with the largest chance that confidences of the prior employer will be betrayed. Its limited range at the same time restricts the threat to the employee's utility in his new job, and eases identification of the settings in which it applies.

The extension of disqualification to rulemaking is seen to involve much larger constraints, in the service of a more diffuse fear of conflict. The broadly shared concerns of a general rulemaking proceeding do not suggest the possibility of self-dealing as sharply as do the particular issues of a proceeding involving a limited number of specific parties. Disqualification now suggests that the government is deprived of experience and policy view, perhaps the very basis on which the official was chosen; or that the individual concerned must fear far larger inhibitions on his future career. To be sure, this is a polar contrast; in some rulemakings the interests of a limited number of parties may be at unique and substantial risk. ${ }^{47}$ But historically rulemaking has been viewed as an activity distinct from the decision of particular, concrete controversy. If one accepts the contemporary judgment that permanent disqualification from participation in general rulemaking is not warranted for the former government employee, then permanent disqualification is also unwarranted in such circumstances for the new government employee. The practical judgment of the past has been that these dangers are too diffuse to support, even for professionals pledged to honor a client's confidences, the very large inhibitions on government choice and employee mobility that would result from general disqualification.

This conclusion does not eliminate the risk of conflicted loyalty or betrayed confidence for the employee who switches camps in the midst of a rulemaking-even one not directly involved in the rulemaking in his former employment. The impact of disqualification in such circumstances may be reduced while still attempting some control over the risk by limiting the duration of disqualification rather than the occasions for it. This appears to be the judgment reflected in the "cooling off periods" in place at the DOE and CAB.

At least three approaches are possible for a "cooling off period" disqualification. First, as the government now imposes on former high level employees, temporary disqualification could extend to all dealings "on the merits" with the former employer. A second approach, the $\mathrm{CAB}$ formula, would preclude employees from working on any matter that was within their official responsibility while in private employ, including rulemaking. The third approach is that embodied in the DOE legislation: a supervisory employee may not act for a time in any matter in which his former employer is interested, other than general rulemaking, or in any matter in which he participated. Each of these formulas embodies compromises reflecting the costs to government of inhibiting job mobility for its present and future employees. In two cases, the restriction is limited to the higher levels of the bureaucratic structure. ${ }^{48}$ Permission is not withheld

47. The spectrum of possibilities, and the difficulty of drawing appropriate distinctions, is similar to that which the Administrative Conference has already faced in connection with its analysis of Home Box Office, see note 23 supra.

48. Individuals holding these positions, it might be thought, have the greatest degree of influence over the outcome of government deliberations, and the greatest job mobility even in the face of 
to advise one's new employer under the Ethics in Government Act or to participate in rulemaking at the DOE or in matters outside former responsibilities at the $\mathrm{CAB}$; each formulation preserves the possibility of acting in some circumstances even though the former employer's interests are involved. One need not choose among the formulations to note that an absolute cooling off period applicable to every employee would exceed any contemporary judgment of sound practice.

Of particular interest for these purposes is the exemption under the Department of Energy Act for participation in general rulemaking. The FCC reports that its more informal practice is similar: in a general rulemaking in which a former employer is one of several participants, commenting as it ordinarily would on a matter of interest to it, a new FCC employee need not withdraw unless he himself was involved in the development of the former employer's position. If the former employer's interests are more directly at stake, then withdrawal is expected. Viewed from the perspective of impact on the former employer, of course, neither the numbers involved nor the generality of the principle proposed necessarily reduces its stake in the outcome. It may still stand to gain or lose mightily, and to that extent the possibility of conflicted loyalties may still appear to advise caution. The FCC practice has overtones of a different consideration: that where the comments may fairly be regarded as "routine," the employee need not withdraw; where the stake is special (even if large numbers may be involved), he must. Such consideration would tend to keep the risk of conflicted loyalties in check; but it is not clearly the practice at the FCC, and is not the requirement applicable at the DOE.

The rulemaking exception, it may be inferred, comes as much from the character and needs of rulemaking as from assessment of the risks of conflict. Several of the responding agencies, discussing generally the need for disqualification procedures in rulemaking, remarked that the large number of individuals who dealt with any given proceeding was itself a safeguard of objectivity in the process. At the same time, and somewhat paradoxically, one could believe that in the setting of general policy an agency has the greatest need to exercise its entire intellectual structure. The institutional process of decision depends on having the full resources of the institution available for decision and-because the full resources are used-is less threatened than would be a judicial process by distortion in any particular part.

3. Redefinition of the Interests that Possibly Conflict? Present financial and occupational conflicts are disqualifying in rulemaking and, for the short term, past ones perhaps should be. Do these judgments extend to occupational conflicts in which the interests of the prior or coordinate employer are not "financial" in character? Liberalized standing rules, and with them vastly expanded participation in agency proceedings, spring from recognition that agency decisions affect interests other than monetary ones-aesthetic, recreational, environmental, etc. Appreciable numbers of individuals have come to government service during the

such constraints. Descending the bureaucratic ladder, it may be surmised, brings one to individuals whose policy influence is not great, whose mobility might well be impaired by constraints on dealing with this or that particular issue within their ordinary ken, and on whom, indeed, the government has a greater need to rely for hard technical advice. 
present administration from organizations active in administrative litigation and rulemaking on behalf of those interests. Some doubtless maintain their membership or even officership in those organizations; if they can be regarded as "charitable, religious, professional, social, fraternal, nonprofit educational and recreational, public service or civic" in nature, the organizations are excepted from the ordinary civil service prohibitions on outside employment. ${ }^{49}$ Should such associations be disqualifying in particular proceedings in which these organizations participate, to the extent they would be if the organizations' interests were financial in character?

The Department of Energy statute discussed above is limited to former "energy concern" employees, and "energy concerns", are defined to include those regulated by the Department and their service industries, but to exclude others who may frequently have a large apparent stake in the outcome of DOE proceedings. This is consistent with the general focus on financial interests. But present and former personal associations can cloud "objectivity" in other ways. It may strike some as odd not to subject to "cooling off" the former employee of the Oregon Public Service Commission or the Union of Concerned Scientists, each of which may have participated vigorously in DOE proceedings and have a substantial institutional stake in their outcome. Retaining active membership in the Friends of the Earth may seem equally a matter of interest, if that organization may be a party. Some agencies, the IRS for example, appear to take the position that at least present relationships of this character are disqualifying; the $\mathrm{CAB}$ rules and FCC practice appear to contain no financial interest limitation; the lawyers' Code of Professional Responsibility would recognize little difference between for-profit and not-for-profit clients. Undoubtedly, many government officials do abstain from participation in rulemaking as well as other forms of decision when they or a former client have been involved in the rulemaking as private participants.

If, as in the situations just described, disqualification is limited to circumstances in which the employee himself participated in or shared responsibility for his prior employer's formulation of a position, a principled distinction from the "financial interest" cases is hard to identify. ${ }^{50}$ The treachery of switching sides, the obligation to protect confidential information, the unseemliness of appearing possibly to be furthering private interests under the guise of seeking the public good, all counsel against participation. An energy concern's

49. 5 C.F.R. $§ 735.203(3)(1980)$.

50. It could be argued, for example, that Texaco employees are likely to perceive employment issues more in economic than in ideologic terms; for employees of the Environmental Defense Fund, the opposite may be true. If one assumes a permanent severance of the prior employment ties on coming to a government job, the EDF employee seems if anything more likely than the Texaco employee to experience a carry-over of his former loyalties. If one assumes that the employee imagines his government service as an interlude to be followed at some indefinite time by return to prior relationships, the former Texaco employee's (hypothesized) continued attention to economic self-interest may distort his actions or judgments; but so may the continued ideological commitments of the former EDF employee. With formal expectations of return, of course, disqualification of both is required. 
perception that its interests are being unfairly dealt with when its former adversary participates in rulemaking seems no less warranted than the complaints the Environmental Defense Fund might have made before the statute's enactment if an energy concern employee had stepped through the "revolving door" into official responsibility for or participation in a rulemaking. A "cooling off period" in either setting would reflect a heightening of the stated standards. In the past, rulemaking has been regarded as outside this kind of conflict of interest concern; but if it is not, the former employee of a participant with important financial interests in the proceeding and the former employee of a participant with other important and legally recognized interests at stake seem comparably situated.

Cooling off periods might have varying effects at different levels of government. For the civil service employee or one appointed by the agency itself, inability to participate in particular policymaking may be an annoyance, but may rarely threaten the overall character of his employment. For an agency head, on the other hand, or one close to the highest levels of government, inability to participate in any significant number of policy matters may be truly disabling, in practical terms approximating a proscription of employment of an individual so situated. Even on a multimember body, the considerations of diversity of view that initially led to the selection of a multimember format will have been defeated unless each member is generally able to participate in important policy affairs. Moreover, for high level employees, the processes of bringing them into government - nomination by the President and confirmation by the Senate-will have served both as a control of ideological precommitments and as some indication that those commitments have been endorsed as appropriate at the highest levels of the political structure. Thus, even if cooling off periods of the type here under discussion were generally regarded as appropriate, an exception might be made for individuals whose appointments are subject to Senate confirmation. To make such an exception risks having a substantial appearance of questionable conduct; policymakers called on to act in matters with which they had been intimately connected in prior private life have often recused themselves for that reason. Nonetheless, a formal interdiction of participation may be inappropriate.

If one turns to a government employee's outside activity while in government employment, the correspondence between financial interests and interests directly implicated in that activity also seems strong. Government generally disclaims interest in charitable, professional, civic, or other like activities of its employees for important reasons: this minimizes intrusions on employee lives; it recognizes and even fosters civic and religious activity; it reflects the general unimportance of such activities to agency functioning; and it acknowledges the unreliability of membership in an organization as an index of attachment to particular positions. Suppose, however, that proposed rulemaking by the FCC is believed by the American Civil Liberties Union strongly to implicate its members' interests in free speech, and thus leads to ACLU participation. If an agency employee is merely a member of the ACLU, that connotes little or nothing; if, however, he is an officer of the organization, or has participated in drawing up its comments, intuition asserts that a conflict of loyalties may arise as disabling 
as those we infer from the possibility of financial self-serving. Official responsibility for the preparation of comments, or substantial and personal participation in that activity, creates a conflict whether the interest of the commenter is financial (in which event the employee's participation is a criminal act) or is otherwise recognized as substantial. Disqualification, it appears, should equally flow.

4. The Six Precepts of Ethical Government Employee Behavior. A basis for even more radical extension of conflict of interest reasoning could be found in Executive Order 11,222 , which sets forth six nonbinding precepts of employee behavior:

An employee shall avoid any action, whether or not specifically prohibited by this subpart, which might result in, or create the appearance of:

(a) Using public office for private gain;

(b) Giving preferential treatment to any person;

(c) Impeding Government efficiency or economy;

(d) Losing complete independence or impartiality;

(e) Making a Government decision outside official channels; or

(f) Affecting adversely the confidence of the public in the integrity of the Government. ${ }^{51}$

Like the criminal provisions of 18 U.S.C. $\S 208$, these precepts do not distinguish between rulemaking and other governmental activity, and apply to all. Agency rules generally include them, although the formulations vary greatly from statements ostensibly binding on the employee ${ }^{52}$ to the merely precatory. ${ }^{53}$ A number of agencies, in responding to the Conference's inquiry, pointed to the precepts (notably (d) and (f)) as a basis for asserting that disqualification could occur in rulemaking. Most acknowledged, however, that enforcement efforts are limited to financial conflicts and associations; and in no agency are the procedures for enforcement adapted to identifying or responding to situations in which "complete independence or impartiality" is lost or "the confidence of the public in the integrity of the Government" is shaken. At present, these matters are left to employee judgment, and the precepts do little more than provide a peg on which a sensitive employee may hang his request to be relieved of particular duties he finds uncomfortable. ${ }^{54}$ Should conflict of interest disqualification extend to every action within reach of these six precepts? In particular, should agency heads or employees withdraw (or be required to do so) whenever some action could appear to compromise their "complete independence or impartiality" or to affect "adversely the confidence of the public in the integrity of the Government'?

51. 5 C.F.R. $\$ 735.201$ (a) (1980). The OPM regulations require agencies to issue regulations embodying a number of prescribed standards, but not these. Id. $\$ 735.201$

52. E.g., 7 C.F.R. $\$ 0.735-5$ ("A violation of this part by an employee may be cause for remedial action ....”), 0.735-11(a) (1980) (verbatim text of 5 C.F.R. $\$ 735.201$ (a), supra note 58) (Dep't of Agriculture).

53. E.g., 10 C.F.R. $\$ 1010.101$ (a) (1979) (DOE “expects that its employees ... will avoid any action....').

54. See, e.g., R. Vaughn, supra note 46 , at 35 . 
Ascribing mandatory force to the precepts would pretermit much of the preceding discussion. While in a formal sense it would remain to determine whether, for example, cooling off periods were required to avoid loss of impartiality, or whether conflict of nonfinancial interests adversely affects the confidence of the public, the venue for that determination would have been shifted to the courts. Since the precepts do not discriminate between rulemaking and other forms of administrative activity, it could be expected that the courts would apply them without making any such distinction. If the precepts were to be judicially rather than self-administered, mandatory rather than hortatory, they might quickly be found to embody premises fully as demanding and subject to the sensitivities of observers as judicial disqualification provisions have proved to be.

Nor do all the precepts state concerns commonly associated with "conflict of interest" analysis. Independence, impartiality, and public confidence can be or appear to be compromised by behavior having little association with conflicting loyalties or self-serving. Dr. Bingham's speech in the lead pollution case or Chairman Pertschuk's remarks in ANA may reasonably be characterized as partisan in some sense; yet neither grew out of any present or past relationship or reflected any personal gain to be achieved. In the usual understanding-reflected in agency practice as shown by the responses to the Conference survey"conflict of interest" concerns are concerns with conflict. ${ }^{55}$ Prejudgment and bias, which may also affect impartiality, independence, and public confidence, are understood to be dealt with under another head. In the absence of the distortions arising from associational conflict or selfish motive, partiality raises no conflict of interest concern.

This conclusion, such as it is, is of course strictly analytical. It does not imply either that nonconflictual partiality in rulemaking is licit or that the six Executive Order precepts are inappropriate goals for the public service to seek or even enforce. Those issues are the business of the next section of this Article. What the conclusion does suggest is that development of conflict of interest analysis is not itself the appropriate vehicle for enforcing the precepts on government employees.

\section{Constraints on Judges: "Bias" and "Animus",}

Conflict of interest principles represent one of three general groupings of concern about the propriety of participation in a government decision. The other two, prejudgment of fact (bias) and prior or irrational commitment (animus), are commonplace concerns in adjudication for which objectivity in the decisionmaker is central, but are foreign to agency rulemaking practice. With exceptions almost wholly limited to conflicts of interest (broadly conceived) or on-the-record proceedings, federal agencies neither administer nor recognize a need for any system of assessing the propriety of participation in rulemaking or policymaking. Even where the agencies' rules do provide for disqualification of presiding offi-

55. Accord, id. at 4-6. 
cers in on-the-record rulemaking, that is most often as part of general procedural rules for all on-the-record proceedings, adopted with adjudication in view. ${ }^{56}$ Assessing the appropriateness of disqualification for bias or animus in rulemaking requires, first, an appreciation of the adjudication model, against which contrasts may appear. That model itself, it will quickly be seen, is not premised on the hopeless aim of obtaining absolute objectivity in the adjudicator. A less ambitious agenda, of open-mindedness respecting the case-unique aspects of the proceeding, characterizes even judicial disqualification rules. The following pages begin with a discussion of disqualification in strictly judicial proceedings and then discuss the practice in agency proceedings resembling trials before moving to consider the possible applications of this analysis to policymaking.

\section{A. Judicial Disqualification}

The requirements of impartiality commonly accepted as apt for the judicial branch of government stand in marked contrast to those applicable in the legislature or to the general run of executive activity. Personal animus toward parties or prejudgments respecting facts in dispute, irrelevancies for legislators and executive personnel (unless the latter happen to be regarded as quasi-judges), are well established grounds for judicial disqualification.

Two statutes, 28 U.S.C. sections 144 and 455, set the current legislative standards for the federal judiciary. Section 144, dealing with alleged "personal bias or prejudice," is essentially unchanged since its enactment in $1911 .{ }^{57}$ Under its provisions, a judge is obliged to disqualify himself on the timely filing of a detailed and sufficient affidavit of "personal bias or prejudice," supported by counsel's certificate of good faith; it was early established that the truth of the matters asserted is not at issue, but only their sufficiency, if true, to establish personal animus or prejudgment. ${ }^{58}$ To reduce judge-shopping, counsel is limited to one such affidavit in each case.

Section 455 , prior to its recent amendments, dealt exclusively with conflict of interest disqualification. Disqualification for interest, early established at

56. The APA provision for disqualification in on-the-record proceedings, 5 U.S.C. $\$ 556(\mathrm{~b})$ (1976), governs both rulemaking and adjudication, and suggests disqualification for "personal bias", of both "presiding employees" and "employees participating in decisions in accordance with section 557." The latter reference is apparently to "an employee qualified to preside at hearings" where the presiding employee is unavailable, id. $\$ 557($ b), or “one of [the agency's] responsible employees" in rulemaking or initial licensing, id. $\S 557(\mathrm{~b})(1)$. Since the responsibilities of responsible employees in rulemaking will often have led them into consultations forbidden to those who preside in on-therecord adjudication, id. $\S 554(\mathrm{~d})(1)$, with results usually described as "personal bias" in settings where such contacts are proscribed, the application of $\S 556(\mathrm{~b})$ to formal rulemaking can certainly vary from that appropriate for adjudication. No suggestion of such a variation appears in the agency rules, although it may be reflected in some agencies' practice.

57. 36 Stat. 1090 (1911).

58. Berger v. United States, 255 U.S. 22 (1921). An example of a dispute over "sufficiency", would be whether the affidavit concerns extrajudicial events, or matters arising during the course of judicial activities. The distorting factors asserted are required to be personal-that is to say, extrajudicial in origin - in the usual case; an affidavit based on the judge's participation in an earlier trial would be regarded as insufficient to establish cause to disqualify. 
common law, ${ }^{59}$ had been required by statute in the Act of May $8,1792,{ }^{60}$ forbidding the sitting of federal district judges "concerned in interest" or who had been "of counsel for either party." Amendments enacted in 1911 called upon a judge to disqualify himself if he was "concerned in interest" in a case, had been of counsel, had been a material witness, or was "so related to or connected with either party as to render it improper, in his opinion, for him to sit." 61 The section's limited statement of principle and highly subjective test led to the conclusion that judges had a "duty to sit," and that in close cases the balance should be tipped toward hearing rather than recusal. ${ }^{62}$

Constitutional analyses of the requirements of fair procedure were equally limited. The leading Supreme Court cases imported little more than that due process forbade the sitting of a judge who was financially interested, directly ${ }^{63}$ or indirectly, ${ }^{64}$ in the outcome of a proceeding, or whose prior contacts with a party were so emotionally charged as to make it appear likely that he would now regard a pending action as his own. ${ }^{65}$ In part, this reluctance to require disqualification was grounded in important policy concerns. Although expansion of the federal judiciary can ease the technical problems created by disqualification, the costs, complications, and delays involved in providing substitute judges remain substantial. Too ready disqualification invites party efforts at disqualification. And it remains true that if

"bias" and "[im]partiality" be defined to mean the total absence of preconceptions in the mind of the judge, then no one has ever had a fair trial and no one ever will. The human mind, even at infancy, is no blank piece of paper. We are born with predispositions; and the process of education, formal and informal, creates attitudes in all men

59. Dr. Bonham's Case, 8 Co. Rep. 107a, 113b, 77 Eng. Rep. 638, 646 (1610), is the decision most often cited, but one whose principles would not have been surprising to jurists of the time. D. Hewitt, Natural Justice 16 (1972). On the common law development, said to have been limited in early cases to allegations of personal interest, see also Frank, Disqualification of Judges, 56 Yale L.J. 605 (1947); Note, Disqualification of Judges for Prejudice or Bias-Common Law Evolution, Current Status, and the Oregon Experience, 48 Ore. L. Rev. 311 (1969); Note, Judicial Disqualification in the Federal Courts, 1978 U. Ill. L.F. 863, 865.

60. I Stat. 278 (1792).

61. 36 Stat. 1090 (1911) (emphasis added).

62. Edwards v. United States, 334 F.2d 360 (5th Cir. 1964).

63. Tumey v. Ohio, 273 U.S. 510 (1927).

64. Ward v. Village of Monroeville, 409 U.S. 57 (1972).

65. Withrow v. Larkin, 421 U.S. 35 (1975), for example, reiterates the position that the combination of investigating and judging functions is not in itself a denial of due process. The Court's several criminal contempt disqualification cases, which might have appeared to stand for the contrary view, in fact involve an additional element - the judge is "victim" as well as "prosecutor" and "judge" of the alleged offense, and this status makes the case far more his "own cause," which he is not fit fairly to judge. See, e.g., Taylor v. Hayes, 418 U.S. 488 (1974); Mayberry v. Pennsylvania, 400 U.S. 455 (1971); In re Murchison, 349 U.S. 133 (1955). Similar concerns seem to underlie the dissent in Hortonville Joint School Dist. No. 1 v. Hortonville Educ. Ass'n, 426 U.S. 482 (1976); the majority, following Withrow, found no constitutional difficulty in permitting a school board that had conducted negotiations during a teacher's strike to impose sanctions on teachers participating in the strike; the dissenters believed disqualification would be required to achieve constitutional fairness if (as was not clear on the record) the board's own conduct during the strike was in issue in any significant respect. All nine Justices agreed that simple knowledge of the circumstances of the strike, acquired in official capacity but dehors a record, was not disqualifying. 
which affect them in judging situations, attitudes which precede reasoning in particular instances and which, therefore, by definition, are pre-judices. . . Interests, points of view, preferences, are the essence of living. Only death yields complete dispassionateness, for such dispassionateness signifies utter indifference.

Much harm is done by the myth that, merely by putting on a black robe and taking the oath of office as a judge, a man ceases to be human and strips himself of all predilections, becomes a passionless thinking machine. ${ }^{66}$

The profession and the public were persuaded, however, to the need for making disqualification standards more explicit by a period of extraordinary turmoil over judicial ethics beginning in the late 1960's. ${ }^{67}$ Closely tracking 1972 revisions to the ABA's Canons of Judicial Ethics, Congress greatly enlarged the scope of mandatory judicial disqualification in 1974 amendments to section $455 .{ }^{68}$ The new version repudiates any "duty to sit" as a policy concern possibly counterbalancing factors suggestive of recusal. The judge is to consult not his own perception of what factors are disqualifying, but the perception of reasonable members of the community. ${ }^{69}$ Concrete examples, not all of them obvious, are given of circumstances in which disqualification is mandatory, ${ }^{70}$ reaching issues of animus and prejudgment as well as an expanded domain of personal interest issues. Particularly striking is the statement of nonwaivable grounds for disqualification seeming to arise from prior connections that may have been wholly intellectual in character: "personal knowledge of disputed evidentiary facts concerning the proceeding," 71 and, for prior government employees, having "expressed an opinion concerning the merits of the particular case in controversy." 72 Both of these legislative statements could be thought to have strong implications for administrative as well as judicial behavior. Closer examination, however, discloses few if any instances of compelled judicial disqualification in the absence of some species of interest in the outcome or personal animus toward a party.

The only explanation of the "personal knowledge" clause is that "a judge cannot be, or cannot appear to be, impartial if he has personal knowledge of

66. In re J.P. Linahan, Inc., 138 F.2d 650, 651-52 (2d Cir. 1943) (Frank, J.).

67. A Supreme Court Justice had been denied the Chief Justiceship and then resigned under pressure; two Supreme Court appointments had failed of confirmation; another Justice had been threatened with impeachment; yet another was sitting in judgment over disputes involving the United States on which he seemed to have expressed views while acting as an Assistant Attorney General. Scandals and partiality at lower levels of the judiciary were also in the news. The story is well told in J. MacKenzie, The Appearance of Justice (1974).

68. Pub. L. No. 93-512, 88 Stat. 1609 (1974).

69. 28 U.S.C. $\$ 455$ (a) (1976): “(a) Any justice, judge, magistrate, or referee in bankruptcy of the United States shall disqualify himself in any proceeding in which his impartiality might reasonably be questioned." What would be "reasonable" questioning is itself a matter in some dispute. See Note, supra note 59, 48 Ore. L. Rev. at 311; Note, Disqualification of Federal Judges for Bias or Prejudice, 46 U. Chi. L. Rev. 236 (1978).

70. 28 U.S.C. $\$ 455(1)(1976)$.

71. Id. $\$ 455(\mathrm{~b})(1)$.

72. ld. $\$ 455(b)(3)$. 
evidentiary facts that are in dispute." 73 Plainly that statement is overbroad. Judges read newspapers, and do not withdraw whenever the credibility of friends or acquaintances may be put at issue, or when in daily life they may have had the chance to form an impression about some matter necessary to decide-for example, the level of noise pollution created by an airport at which the judge has sometimes lunched. Discussion in and out of the cases uniformly refuses to find a need for disqualification in such circumstances. ${ }^{74}$ Cases identified in the most extensive treatise treatment as supporting the "personal knowledge" proposition all involve situations in which prior, ex parte contacts had been made by one party to the case, thus creating an appearance of favoritism, bias, or prejudice, as well as "prejudgment." 75 No case yet found holds that simple exposure to controversy in the community, without more, is enough.

A well settled and important narrowing of the statute's language is that knowledge previously acquired in a judicial capacity is not "personal" knowledge. ${ }^{76}$ Of course such official knowledge of the facts may be equally condu-

73. Thode, Reporter's Notes to Code of Judicial Conduct 62 (1973) [hereinafter cited as Thode, Reporter's Notes]. Professor Thode was reporter to the ABA's special committee, and his work is widely regarded as important "legislative history" of the Code. Compare Rehnquist, Sense and Nonsense About Judicial Ethics, 28 The Record 694 (1973).

74. "The disqualification provision is directed toward knowledge of disputed evidentiary facts, that is, matters underlying the cause of action. We do not understand the statutory language to be directed toward routine judgments of credibility. . . . Congress did not intend to disrupt the court's business on such inadequate grounds." Plechner v. Widener College, 569 F.2d 1250, 1263 (3d Cir. 1977); see also United States v. Haldeman, 559 F.2d 31 (D.C. Cir. 1976), cert. denied, 431 U.S. 933 (1977); Parrish v. Board of Comm'rs of Ala. State Bar, 524 F.2d 98, 104 (5th Cir. 1975) ("Credibility choices are not disputed facts."'); United States v. Conforte, 457 F. Supp. 641 (D. Nev. 1978) (judge would have to have disqualified self if a juror); Town of E. Haven v. Eastern Air Lines, 304 F. Supp. 1223 (D. Conn. 1969).

In Commonwealth v. Perry, $468 \mathrm{~Pa}$. 515, 364 A.2d 312 (1976), a trial judge who had been friendly with a murdered policeman and attended his funeral was held not to have violated canon $3 \mathrm{C}$ (1) by presiding at the resulting homicide trial. While one may believe here, with Professor Thode, The Code of Judicial Conduct-The First Five Years in the Courts, 1977 Utah L. Rev. 395, 402-03 [hereinafter cited as Thode, Code of Judicial Conduct], that the dissent in the case has more merit, surely that is because the threat of partiality has crept in along with that of prior exposure to "fact." As in the criminal contempt cases, see note 65 supra, there is reason to fear the case has become the judge's own. Putting critical reaction aside, however, the fact of this decision confirms the test: "personal knowledge of the facts" may refer to what is known by a potential material witness, or what results from inappropriate contact by a party (suggestive of favoritism); it does not refer merely to acquaintance with versions of the facts acquired through ordinary life in the community.

75. 13 C. Wright, A. Miller \& E. Cooper, Federal Practice \& Procedure $§ 3543$ (1975).

76. The cases are collected and discussed at id. $\$ 3542 \mathrm{nn}$. 10-14. An excellent, illustrative, and frequently cited example is In re Fed. Facilities Realty Trust, 140 F. Supp. 522 (N.D. Ill. 1956). See United States v. Grinnell Corp., 384 U.S. 563, 583 (1966). At some point a reviewing court may be convinced that the trial court has become so emotionally involved with one side or the other as to foreclose necessary detachment. See, e.g., Nicodemus v. Chrysler Corp., 596 F.2d 152 (6th Cir. 1979); Reserve Mining Co. v. Lord, 529 F. 2d 181 (8th Cir. 1976). Such cases seem to be characterized by intemperance of expression toward one side or by evident emotionality beyond simple disbelief, and expressions in the opinions make one suspect that the reviewing judges believe the sitting judge to be often unjudicial in mien. They may also be cases involving the need to administer a remedy, or other circumstances that force the judge to deal with the parties and assess their good faith over relatively long periods of time. Once a judge is drawn to question the good faith of a party he has, of necessity, failed to remain "detached from the conflict between the parties." Id. at 186. See generally Fiss, Foreword: The Forms of Justice, 93 Harv. L. Rev. 1, 53-56 (1979). 
cive to prejudgment or, where a party is abrasive, animus. Judges make preliminary determinations before trial that inevitably shape their view of the facts to be proved - in criminal cases (e.g., probable cause hearings) as well as during civil discovery and pretrial conference; in ex parte (on applications for warrants and temporary restraining orders) as well as in bilateral proceedings. They try again cases in which they have been reversed on appeal; pass on motions for postconviction relief or parole revocation in cases in which they earlier convicted the party in crime. But these prejudgments are not disqualifying, as United States $v$. Wolfson $^{77}$ illustrates. Wolfson wished to disqualify District Judge Palmieri from passing on his application for postconviction relief. Wolfson had twice been a defendant before the judge, had unpleasant exchanges with him during and after the trials, and subsequently sent him unfriendly communications. The circumstances did not suffice to disqualify the judge. Personal bias, the Second Circuit stated, "must stem from an extra-judicial source", ${ }^{78}$ the letter and telegram Wolfson had sent may have shown his feelings toward the judge, but not the reverse.

At one level, the refusal to find prior judicial exposure disqualifying represents an accommodation to the needs of a busy judicial system; at another, a safeguard against the manipulation that could occur if a defendant - or any party who began to see the wind blowing against him - could secure recusal by outrageous behavior or by pointing out the judgment in the process of formation. "If the judge did not form judgments of the actors in those court-house dramas called trials, he could never render decisions." 79 Equally important, however, is the perception that these prejudgments, officially rather than "personally" reached, do not compromise the deciding officer. Because these judgments are professional ones, they are thought not to produce or threaten the same level of psychological commitment to outcome as would more personal involvements. The judges may be "assumed to be men of conscience and intellectual discipline, capable of judging a particular controversy fairly on the basis of its own circumstances." 80

Knowledge of "disputed evidentiary facts" refers not only to knowledge acquired in a certain way, but also to "facts" of a directly testimonial and case-unique character. We have already suggested the distinction between the questions whether Jones was fired on account of race, and whether segregated education is harmful to the development of children. The latter question does raise factual issues, issues on which testimony and dispute can readily be imagined; but no particular observable events are uniquely central to that testimony, and resolution of those issues has a significance stretching well beyond the particular case in which they may be presented. The use of judicial notice, of "factual" advocacy based on materials never placed on record at a trial, has long

77. 558 F.2d 59 (2d. Cir. 1977); accord, In re Int'l Bus. Machines Corp., 618 F.2d 923 (1980).

78. 558 F.2d at 62 .

79. In re J.P. Linahan, Inc., 138 F.2d 650, 654 (2d Cir. 1943).

80. United States v. Morgan, 313 U.S. 409, 421 (1941). See Withrow v. Larkin, 421 U.S. 35 (1975). 
been tolerated, and no case suggests that disqualification would be appropriate when it has occurred. ${ }^{81}$ Thus, it is not sufficient that a given matter is susceptible of evidentiary dispute; prior exposure to "facts" has seemed important to disqualification in the judicial context only where the facts in question are unique to the parties, requiring, not merely permitting, testimony for their elucidation and resolution.

The distinction thus suggested is essentially Professor Davis's oft-referred-to distinction between "legislative" and "adjudicative" fact. While, prior to the decision in $A N A$, no court or legislature seems to have referred to it in discussing judicial disqualification, the distinction was central to consideration of the closely related issue of judicial notice. ${ }^{82}$ Rule 201 of the Federal Rules of Evidence now places constraints on the use of judicial notice-in other words, requires trial-only for matters of "adjudicative fact" as Professor Davis has defined them - "the facts of the particular case," those "which relate to the parties," as distinct from those "which have relevance to legal reasoning and the lawmaking process," such as whether adverse testimony given in criminal proceedings by one spouse against another would be likely to destroy almost any marriage. ${ }^{83}$ If the dispute is one readily submitted, in our traditions, to legislative resolution, then the underlying factual questions do not come within the reach of the formal constraints on judicial notice established by rule 201, however possible or even desirable it may be to resolve that dispute when it arises in a trial by evidence subject to cross-examination. ${ }^{84}$ Nor, so far as can be deter-

81. Accord, Note, Bias in Administrative Rulemaking After Association of National Advertisers v. FTC, 54 Notre Dame Law. 886, 895-98 (1979); but compare $A N A$, slip op. at 34-35 n.11 (MacKinnon, J., dissenting).

82. Judicial notice rules, like ex parte contact rules and disqualification rules in the context here under discussion, are concerned with how judges acquire information, the necessary relation of the parties to that process, and the control by the parties of it. Rules respecting judicial notice and ex parte contact, however, usually provide a much milder remedy (notice and opportunity to respond) than bias rules, for which the remedy is disqualification. See, e.g., J. Weinstein \& M. Berger, Weinstein`s Evidence 200-18 (1979). Only in extreme cases are ex parte contacts apparently thought to require disqualification as a remedy; no judicial notice error has been found which led a court to impose that sanction on the noticing judge. Cf. Fox v. City of W. Palm Beach, 383 F.2d 189 (5th Cir. 1967) (judge noticed highly disputable facts about land character on the basis of prior personal ownership of similar land; reversed for retrial, apparently before same judge). In the absence of a personal stake, it appears to be assumed that the judge, informed of his error, will be fully capable of an impartial retrial. If taking judicial notice of a given fact is not error-or if error, is readily corrected by affording an opportunity for responsive demonstration - having "personal knowledge" of the same material can hardly be, without more, sufficient ground for the more extreme step of disqualification.

83. See Advisory Committee's Note to Fed. R. Evid. 201(a).

84. The distinction between adjudicative and legislative facts is not, as litigators sometimes assert it to be, one between matters susceptible of evidentiary proof at a trial and those that are not. One can imagine experts testifying richly about the impact of spousal testimony on marriage survival, and vigorous cross-examination of them respecting their views and the experimental basis on which they rest. Nor do the comments on rule 201 deny that a judge required to decide some controverted issue of legislative fact may sometimes find it advisable to use the medium of trial-type procedure. Unconstrained judicial notice is not always desirable for "legislative facts." But those who drafted rule 201 were unable to formulate a general principle that would not be too constraining on judicial disposition of these more general issues, issues not unique to the parties and to the particular circumstances of the litigation. Compare the discussion of similar difficulties in connection with Congress's adoption of the Magnuson-Moss Act in the majority's opinion in the ANA case, slip op. at 
mined, have such factual disputes ever been the occasion for disqualification of a judge found to have "personal knowledge" of them.

Disqualification of judges for their views of policy or law presents far simpler issues; the law unequivocally regards attitudes on legal or policy issues as lying outside the perimeters of concern with bias or prejudgement. ${ }^{85}$ The statute, like the ABA canons on which it draws, speaks only of interest, attitude toward a party, or extrajudicial knowledge of the "disputed evidentiary facts" as grounds for disqualification. ${ }^{86}$ Although reserve in public commentary about pending proceedings is called for in $\mathrm{ABA}$ canon $3 \mathrm{~A}(6)$, that canon is limited to the particulars of the case, and violation of it is not disqualifying. As Justice Rehnquist remarked in a notable memorandum explaining a refusal to disqualify himself in Laird v. Tatum,

Since most Justices come to this bench no earlier than their middle years, it would be unusual if they had not by that time formulated at least some tentative notions that would influence them in their interpretation of the sweeping clauses of the Constitution and their interaction with one another. It would be not merely unusual, but extraordinary, if they had not at least given opinions as to constitutional issues in their previous legal careers. Proof that a Justice's mind at the time he joined the Court was a complete tabula rasa in the area of

23-25. The majority concludes that there may be a third class of fact - "specific fact" - narrow in focus and material to the outcome of rulemaking, yet "legislative" in character, which it is reasonable to find using trial-type techniques. Its principal reliance is on legislative history deriving from the Administrative Conference and its officers.

Rather than view the distinction from the perspective of what may be litigated one could approach it from the perspective of what can be legislated. That is, one could say that an adjudicative fact is one that, in our traditions, cannot be fairly resolved contrary to private interest by a legislature but requires a trial; is one that, in appropriate circumstances, would excite bill of attainder concerns; or is one as to which, in Professor Davis's terms, we have made "the practical judgment on the basis of experience, that taking evidence, subject to cross-examination and rebuttal, is the best way to resolve controversies .... . K. Davis, A System of Judicial Notice Based on Fairness and Convenience, in Perspectives on Law 69, 93 (1964) (emphasis added).

85. While this outcome is not beyond intellectual question, see Downing, Judicial Ethics and the Political Role of Courts, 35 L. \& Contemp. Prob. 94 (1970), no one has yet suggested a practical alternative.

86.

Subsection (a) has gone through several formulations in drafting. At one time the language provided for disqualification if a judge "had a fixed belief concerning the merits." It was intended that a judge disqualify himself if he had made up his mind on the merits before he heard the case. The Committee was confronted, however, by the interpretation of many able judges and law professors that would require a judge to disqualify himself if he had a fixed belief about the law applicable to a given case. For example, it was argued that a judge with a fixed belief that the First Amendment precludes a libel action by a public official against a newspaper in the absence of proof of malice should disqualify himself in a libel case of that general character. This interpretation was not intended; indeed, the Committee recognized the necessity and the value of judges' having fixed beliefs about constitutional principles and many other facets of the law. As a result of the apparent ambiguity of the proposed language, the Committee adopted instead the standard of "personal bias or prejudice."

Thode, Reporter's Notes, supra note 73 , at 61 . 
constitutional adjudication would be evidence of lack of qualification, not lack of bias. $^{87}$

The circumstances of this case are instructive. While an Assistant Attorney General, the Justice had appeared before Senate committees as a witness on the legal issues involved in the case, and had twice had to refer to the case itselfthen pending in lower courts - although in respects not at issue before the Supreme Court. In adopting section 455, Congress revised the ABA canon in a way that might seem a direct response to Justice Rehnquist's refusal to withdraw. A former government attorney must disqualify himself, it provided, not only when he has acted as counsel, adviser, or material witness in the case, but also where he has "expressed an opinion concerning the merits of the particular case in controversy.," 88 This might be thought a repudiation of the established view, making a judge's expression of policy or legal views during a prior period of government service a ground for disqualification.

No such intent is expressed by the legislative history, however; it refers to Justice Rehnquist's memorandum but gives no indication whether he is thought to have been right or wrong in his decision to participate. A close analysis of the problem of disqualification of former government attorneys, relied on in part by Justice Rehnquist, reached the historical conclusion that "Justices disqualify in government cases when they have been directly involved in some fashion in the particular matter, and not otherwise ... . [and] do not disqualify merely because the particular matter involves a policy which, when in the government, they may have helped to form." 89 The language of section 455 is consistent with this practice, if "the merits of the particular case" is understood to refer to the outcome of the case between the parties, on its unique facts, and not to the outcome of any legal questions involved. The ethical ill to which the subsection is addressed appears to be one of animus rather than intellectual predisposition - that the judge has committed himself personally to one of the contending parties, rather than that he has views about the appropriate rule of law to be applied. So viewed, the statute adopts a rule comparable to that which precludes a judge from participating in appellate review of his own trial decisions, but permits him to review other cases involving identical legal or policy issues. The application of this provision to Justice Rehnquist's sitting in Laird $v$. Tatum is at best controversial; ${ }^{90}$ but prior general legal or policy views remain firmly nondisqualifying.

87. Laird v. Tatum, 409 U.S. 824, 835-39 (1972). Justice Rehnquist also reviews at length the history of practice by Supreme Court Justices, a history in which labor partisan Frankfurter did not hesitate to sit on cases involving disputes over the meaning of the Norris-LaGuardia Act, which he helped to draft; and former Senator Black sat to assess the constitutionality of legislation he had championed in the Senate.

88. 28 U.S.C. $\$ 455(\mathrm{~b})(3)(1976)$.

89. Frank, Disqualification of Judges: In Support of the Bayh Bill, 35 L. \& Contemp. Prob. 43, 50 (1970).

90. In their treatise on federal civil procedure, supra note 75, Professors Wright, Miller, and Cooper at first concluded that this must be disqualifying; they subsequently recanted that view, remarking that the Justice's testimony, as relevant to the issues before the Court, dealt only with general propositions of law. Compare id. $\$ 3544$ n.7 with id. (Supp. 1980). But see Thode, Code of Judicial Conduct, supra note 74 , at 403 n. 36 . 


\section{B. Administrative Disqualification in On-The-Record Proceedings}

1. Statutory Provisions. The Administrative Procedure Act provides that in any on-the-record proceeding:

A presiding or participating employee may at any time disqualify himself. On the filing in good faith of a timely and sufficient affidavit of personal bias or other disqualification of a presiding or participating employee, the agency shall determine the matter as a part of the record and decision in the case. ${ }^{91}$

This language does not embody the detailed provisions of 28 U.S.C. section 455 , although they may be looked to for guidance. As important for present purposes, what may be disqualifying is limited by the implications of the Act's more specific provisions respecting internal separation of functions. ${ }^{92}$ These provisions limit the kinds of conversations agency decisionmakers may have with fellow employees in on-the-record proceedings, limitations equally concerned with preserving the conditions necessary for objective decisionmaking. But these provisions are strikingly limited in their application. "An employee or agent engaged in the performance of investigative . . functions" may "participate or advise in the decision" of an on-the-record rulemaking, initial licensing, or ratemaking. To this extent, prior associations that today would plainly be regarded as disqualifying in a judicial context are not made disqualifying in onthe-record rulemaking, licensing, or ratemaking. ${ }^{93}$ For agency members themselves, disqualification is apparently never required for prior performance of of ficial functions that a judge might regard as inconsistent with their agency role.

The legislative history of the APA provisions strongly suggests that the drafters' concerns were with the personal animosities and commitments arising from an investigator's or prosecutor's active pursuit of a particular adversary, and not with intellectual commitments arising out of prior consideration of an asserted fact. Thus, in discussing the need for separation of adjudicatory function from investigating and prosecuting, the Final Report of the Attorney General's Committee carefully draws a line between those who actually investigate and prosecute and those who make the intellectual assessment whether on a given set of asserted facts a prosecution should be brought. The former suffers the "personal psychological" disqualification of having so "buried himself in one side of an issue [that he is] disabled from bringing to its decision that dispassionate judgment which Anglo-American tradition demands"; the latter-generally including the agency head - need make no such commitment to the asserted

91. 5 U.S.C. $\S 556(b)(1976)$

92. Id. $\S 554(\mathrm{~d})$.

93. Regulatory reform proposals pending before Congress would eliminate this distinction. See S. 262, 96th Cong., 1st Sess.; S. 2147, 96th Cong., 1st Sess.; H.R. 3263, 96th Cong., 1st Sess. At this point, however, the purpose is not so much to defend the distinction, which is widely regarded as unfair for proceedings required to be decided on the record, as to illustrate by resort to existing legal doctrine what has been the agreement on application of disqualification principles to administrative practice. The pending proposals would not apply to informal ratemakings. See also note 19 supra, discussing recent changes made by the FTC Improvements Act of 1980. 
facts. ${ }^{94}$ The reports in both houses of Congress refer to "accusatory" proceedings as the ones for which this separation of functions is required. ${ }^{95}$ Perhaps most telling in this respect is the discussion in the Attorney General's Manual on the APA, ${ }^{96}$ which identifies the presence of "accusatory or disciplinary factors" as a necessary condition of applying the separation of functions requirement. The "personal psychological" commitment of investigators or prosecutors vis-à-vis particular individuals would not, in the Attorney General's view, disqualify them from assisting in the decision of cases involving other persons "merely because the facts of [the latter case] may form a pattern similar to those which they had heretofore investigated or prosecuted"; identity of parties was the disqualifying element. ${ }^{97}$ Although a general counsel could not fairly advise the agency how to decide an accusatory proceeding in which he had been substantially involved, his "participation in rule making and in court litigation would be entirely compatible with his role in advising the agency in the decision of adjudicatory cases." 98 Actual commitment to one side in a particular accusatory or disciplinary battle, not simple exposure to factual materials, thus appears to have been the principal concern. ${ }^{99}$

2. The Supreme Court Cases. The decisions of the Supreme Court, some already briefly discussed, ${ }^{100}$ suggest that even in accusatory proceedings, involving specific parties and directed to the imposition of a sanction, mandatory dis-

94. S. Doc. 8, 77th Cong., 1st Sess. 56-57 (1941). Practical considerations also are important: the individuals who actually investigate and prosecute can be separated from the decisional function without significant impairment of efficiency. But policy decisions respecting the initiation of actions cannot readily be separated from assessing the results of those actions.

95. Legislative History of the Administrative Procedure Act, S. Doc. No. 248, 79th Cong., 2d Sess. 24-25 (1946); S. Rep. No. 752, 79th Cong., 1st Sess. 18 (1945) (agencies are advised not to apply the exceptions in ratemaking or licensing cases that prove to be "accusatory in form and involve sharply controverted factual issues," for the exceptions are not meant to preclude "fair procedure where it is required"'); H.R. Rep. No. 1980, 79th Cong., 2d Sess. (1946). The Senate Judiciary Committee print would specifically have required disqualification where there had been a willful breach of separation of functions by a hearing officer, but that provision did not emerge from committee. S. Doc. No. 248, 79th Cong., 2d Sess. 29 (1946) at 29.

96. U.S. Dep't of Justice, Attorney General's Manual on the Administrative Procedure Act $51-58$ (1947).

97. Id. at 54 n.6. See also Jonal Corp. v. District of Columbia, 533 F.2d 1192 (D.C. Cir. 1976), cert. denied, 429 U.S. 825 (1976).

98. Attorney General's Manual, supra note 96, at 58 n.8. Cf. American Gen. Ins. Co. v. FTC, 589 F.2d 462 (9th Cir. 1979), in which Commissioner Collier was disqualified in the Commission's proceeding against American General for having previously served as counsel in a related court of appeals proceeding. Had he previously appeared as an advocate before the Commission in the case, his disqualification would have been required by uniform judicial practice, $\S 455$, and prior decisions, e.g., Trans World Airlines v. CAB, 254 F.2d 90 (D.C. Cir. 1958). But the appearance here was on review of the Commission's judgment; as the Commission's attorney, Collier was bound to take no position other than its own; if he thus became "committed" to a particular outcome, it is hard to understand why his commitment should be regarded as greater or more prejudicial than that of the commissioners whose judgment he defended. Those commissioners, of course, remained free to decide the issue. This line of analysis was not discussed by the court.

99. There appears to have been no direct consideration of what was meant by disqualifying bias, it presumably being understood that prevailing judicial norms would be applied. These were permissive, as has already been remarked. See, e.g., NLRB v. Donnelly Garment Co., 330 U.S. 219 (1947).

100. See text accompanying notes $63-65$ supra. 
qualification requires a distinctly personal interest (whether financial or emotional) in the outcome of the particular case. When the Secretary of Agriculture reacted with strong emotion to Supreme Court decisions adverse to him in the famous Morgan litigation, ${ }^{101}$ the fact "that he not merely held, but expressed, strong views on matters believed by him to have been in issue, did not unfit him for exercising his duties in subsequent proceedings ordered by this Court." 102 The views expressed had neither impugned the parties nor concerned any particular facts he had to decide respecting them.

Similarly, in a proceeding seeking to impose the sanction of a cease and desist order, it was not disqualifying that members of the FTC had engaged in an ex parte study of the very practices engaged in by the defendants in the proceeding and had reported to Congress their view that the practices were in violation of the law. The case, FTC $v$. Cement Institute ${ }^{103}$ is frequently discussed as if it involved precommitments of a policy nature only, but the Court assumed that those views were based on the investigation's results-i.e., on prior exposure to fact. "[T] hat the Commission had entertained such views . . . did not necessarily mean that the minds of its members were irrevocably closed...." The prior exposure was official and unrelated to any particular party or case-of a piece with Congress's purpose to permit commissioners " "to acquire the expertness in dealing with these special questions concerning industry that comes from experience.' , ${ }_{104}$ To be contrasted was the decision in Tumey $v$. Ohio, ${ }^{105}$ where there had been a "direct, personal, substantial, pecuniary interest in reaching his conclusion to convict.", 106

The absence of a "personal psychological" commitment, as distinct from a commitment ascribable to the performance of official function, was also central to the Court's refusal to find disqualifying bias in Withrow v. Larkin. ${ }^{107}$ That case involved a state medical board responsible both for selecting professional discipline cases for prosecution and for deciding those not referred to criminal prosecution. This combination of functions, it was argued, offended constitutional requirements of fair procedure. The Court rejected the argument. It identified "cases . . . in which the adjudicator has a pecuniary interest . . . and in

101. United States v. Morgan, 313 U.S. 409 (1941).

102. Id. at 421 .

Cabinet officers charged by Congress with adjudicatory functions are not assumed to be flabby creatures any more than judges are. Both may have an underlying philosophy in approaching a specific case. But both are assumed to be men of conscience and intellectual discipline, capable of judging a particular controversy fairly on the basis of its own circumstances.

Id.

103. 333 U.S. $683,700-03$ (1948).

104. Id. at 702 (citing Report of Comm. on Interstate Commerce No. 597, 63d Cong., 2d Sess. $10-11(1914))$.

105. 273 U.S. 510 (1927).

106. The Court also relied upon the absurdity that would result from disqualification of the entire Commission - in effect, the doctrine of necessity. It may be noted, however, that this concern was expressed as only an alternative ground of decision, and that "necessity" has not prevented the Court from disqualifying an entire tribunal where substantial personal interests of its members so require. Id.; Gibson v. Berryhill, 411 U.S. 564 (1973).

107. 421 U.S. 35 (1975). See note 65 supra. 
which he has been the target of personal abuse or criticism from the party before him" as presenting too high a probability of actual bias to be constitutionally tolerable. But it concluded that "a realistic appraisal of psychological tendencies and human weakness" did not require the same conclusion for the combination of investigative with adjudicatory function; the prior exposure to adjudicatory fact which follows from that combination did not imply an incapacity for objectivity on the record. ${ }^{108}$

The distinction parallels that already encountered for judicial disqualification between prior personal (extrajudicial) contact with a case and prior official contact. Where the decider has acted officially, he is presumed to be able to overcome his prior inclinations, knowledge, or conclusions; it is prior personal involvement that produces irrational attachment to the possibly erroneous first view. This presumption of objectivity when acting in role can be defeated in particular cases by demonstrating actual irrationality in behavior. But the line between what is learned in role and what is learned outside of role is nonetheless a major reference point.

Like many hypotheses about the rich complexities of human behavior this one is more the product of practical necessity and historical acceptance than rigorous scientific demonstration. Doubtless a criminal defendant ordered to trial again before the judge whose verdict he has just had reversed on appeal worries that his burden may be greater now than it previously was, and so it may be. But the community's resources are limited; for centuries judges have been retrying cases, and passing on the presence of both prima facie showings and proof of guilt, without notable outcry or demonstration of unfairness; to eliminate these practices would make public administration more costly and cumbersome. Moreover, the judges who have to decide these issues perceive in themselves and in centuries of professional tradition a capacity in fact to learn from and surmount demonstrations of past error, and to maintain a "professional" attitude toward matters put before them. These perceptions could be challenged, but they persist and are supported by history and widespread judicial confidence. They are also readily ascribed to administrators performing similar functions. Moreover, in both contexts, the practical advantages of belief in them are substantial.

For administrators, roles are far less confined than they are for judges, and so the sweep of what may be learned and the possible opportunities for a prejudgment may seem greater, even when the administrator acts entirely within role. Yet the Supreme Court does not appear to have concluded that only those official functions that would also be performed by a judge consistent with judi-

108. The Court remarked, in distinguishing In re Murchison, 349 U.S. 133 (1955), that it was of course possible that unacceptable risks of bias might "lurk in the way particular procedures actually work in practice." The issue of concern on that analysis, however, would be the same as that identified in the text-whether the circumstances shown were so likely to produce a personal psychological attachment to a particular outcome as to defeat the assumption that the officers are " 'men of conscience and intellectual discipline, capable of judging a particular controversy fairly on the basis of its own circumstances." " 421 U.S. at 55, quoting United States v. Morgan, 313 U.S 409, 421 (1941). 
cial duty are consistent with fairness in adjudicative activities. Judges do not make ex parte investigations and report to Congress, as did the Commissioners in Cement Institute; nor do they initiate the filing of charges, as did the Board in Withrow. Indeed, the Court in Withrow indicated its approval of Pangburn $v$. $C A B$, a First Circuit decision finding no constitutional unfairness in the CAB's both performing a "Congressional mandate to investigate and report the probable cause of all civil air accidents" for a recent accident and subsequently hearing a disciplinary proceeding against a pilot involved in that accident, whose conduct the report had criticized. ${ }^{109}$ The Court simultaneously witheld its approval of some lower court holdings that had found due process violations, apparently in reliance on the judicial analogy. ${ }^{110}$

3. The Court of Appeals Cases. The court of appeals opinions on agency disqualification in on-the-record adjudications have been generally consistent in result if not always in expression, with the distinction between "personal psychological" influences and judgments reached or expressed in the course of official business. ${ }^{111}$ Quite naturally, however, the courts of appeals have often been more deeply involved in the particular facts of the cases before them. Three cases in particular, all influential, convey a tone very different from the Supreme Court cases.

Two of the cases, Texaco, Inc. v. FTC ${ }^{112}$ and Cinderella Career \& Finishing Schools, Inc. v. FTC, ${ }^{113}$ arose out of speeches made by FTC Chairman Paul Rand Dixon during the pendency of adjudication. In each case, the speech was interpreted by a party and the courts as indicating that the Chairman had made up his mind in advance of decision, and therefore must be disqualified. No prior unofficial connection with the cases, interest, animus, or other "personal psychological" commitment appears to have been shown. So far as appears, it is merely that while the cases were pending on the docket and not decided, Chairman Dixon spoke about them in a way that conveyed the impression that he had made up his mind. The court in both cases expressed as the test for disqualification whether " 'a disinterested observer may conclude that [the Commissioner] has in some measure adjudged the facts as well as the law of a particular case in advance of hearing it.' "' 114

109. 421 U.S. at 50-51 n.16, quoting Pangburn v. CAB, 311 F.2d 349, 358 (1st Cir. 1962).

110. 421 U.S. at $50-51$ n. 16 .

111. Thus, Chairman Dixon of the FTC was disqualified in American Cyanamid v. FTC, 363 F.2d 757 (6th Cir. 1966), on account of his prior active service as counsel to an aggressive Senate subcommittee concerned with the same facts and issues. But compare Safeway Stores, Inc. v. FTC, 366 F.2d 795, 801-02 (9th Cir. 1966). Commissioners of the SEC and the CAB were disqualified on the basis of their advocacy roles prior to becoming commissioners in Amos Treat \& Co. v. SEC, 306 F.2d 260 (D.C. Cir. 1962), and Trans World Airlines v. CAB, 254 F.2d 90 (D.C. Cir. 1958), respectively. But $\mathrm{FTC}$ and $\mathrm{CAB}$ commissioners who as commissioners pursued investigations to develop, and reached conclusions about, facts later put at issue in sanction-seeking adjudication were not disqualified. FTC v. Cement Inst., 333 U.S. 683 (1948); Pangburn v. CAB, 311 F.2d 349, 358 (1 st Cir. 1962). Compare the discussion of "structural"' as opposed to "individual" prejudgment in Porter County Chapter v. NRC, 606 F.2d 1363, 1370-72 (D.C. Cir. 1979).

112. 336 F.2d 754 (D.C. Cir. 1964), vacated on other grounds, 381 U.S. 739 (1965).

113. 425 F.2d 583 (D.C. Cir. 1970).

114. 336 F.2d at $760 ; 425$ F.2d at 591 . Both courts cited for this formulation Gilligan, Will \& Co. v. SEC, 267 F.2d 461, 469 (2d Cir.), cert. denied, 361 U.S. 896 (1959). But in that case 
A striking characteristic of both opinions is that the conclusion drawn by the court - that Chairman Dixon was addressing the merits of particular cases in his speeches - is not an obvious one. Cinderella, for example, concerned an FTC fraud action against a vocational school alleged to have falsely promised training that would lead to jobs as airline hostesses. The school's complaint arose from Chairman Dixon's address to a convention of newspaper publishers, seeking to build understanding and support for Commission policy - a responsibility common to commissioners but foreign to judges. As one familiar with wide varieties of consumer fraud, he called on the publishers to exercise some vigor in screening advertisements for possible fraud and gave a series of examples of what he had in mind - a merchant's periodic "going out of business" sale, offering college educations in five weeks or fortunes from raising mushrooms in the basement, eliminating pimples with a magic lotion, becoming a stewardess by attending charm school. ${ }^{115}$ Dixon did not mention the Cinderella Career and Finishing School or any particular facts of their case that might have shown whether it did or did not make fraudulent claims. To this writer it is not surprising that after a few years on the job, an FTC commissioner could regard any of the stated claims as prima facie evidence of consumer fraud, an attitude that would not be disqualifying so long as the commissioner remained able to decide whether a particular defendant had in fact made such claims. But to the court, this speech marked Dixon as "insensitive," a man of "questionable discretion and very poor judgment," and led it to disqualify him. ${ }^{116}$ In the Texaco case, too, Chairman Dixon's words were less conclusive of factual prejudgment than is often assumed. ${ }^{117}$

disqualification was refused; the language appears there merely as part of precatory advice to the Commission that to preserve its "reputation for objectivity and impartiality" it should write press releases about pending cases in a restrained manner.

115. 425 F.2d at 589-590. The court regarded the college and charm school claims as references to Cinderella.

116.

It is appalling to witness such insensitivity to the requirements of due process; it is even more remarkable to find ourselves once again confronted with a situation in which Mr. Dixon, pouncing on the most convenient victim, has determined either to distort the holdings in the cited cases beyond all reasonable interpretation or to ignore them altogether. We are constrained to this harshness of language because of Mr. Dixon's flagrant disregard of prior decisions.

425 F.2d at 590-91.

117. In Texaco, Chairman Dixon spoke to the National Congress of Petroleum Retailers after the Commission had finally decided charges of price fixing, price discrimination, and overriding commissions brought against a number of firms supplying gasoline and accessory parts to the dealers; a case against Texaco and Goodrich remained pending, however, in light of an earlier remand. Chairman Dixon said:

We at the Commission are well aware of the practices which plague you and we have challenged their legality in many important cases.

You know the practices-price fixing, price discrimination, and overriding commissions on TBA.

You know the companies-Atlantic, Texas, Pure, Shell, Sun, Standard of Indiana, American, Goodyear, Goodrich, and Firestone.

Some of these cases are still pending before the Commission; some have been decided by the Commission and are in the courts on appeal. You may be sure that the 
One might explain these results as the product of Dixon's strong personality, ${ }^{118}$ or perceptions by the court that he had been unresponsive to its concerns. ${ }^{119}$ More broadly, it could be suggested that much of the law of bias and disqualification involves the enforcement of rules of decorum, the disciplining of verbal ruffians more than the attainment of actual objectivity in factfinders. Of course judges know that an administrator's repeated exposure to challenged commercial conduct will give him strong ideas about what types are fraudulent - often well in advance of decision in a particular case. ${ }^{120}$ They know, too, that the official functions of administrators, unlike judges, include keeping the public and the legislature informed of what they are doing and the policies they are enforcing. In the context of administrative sanctioning, however, vigorous public statement of these ideas or pursuit of these functions threatens common understandings of fairness. Judges do not decide to bring prosecutions, give luncheon speeches, testify to Congress, or issue press releases. The judicial nerve may be set on a hair-trigger by the fact that adminis-

Commission will continue and, to the extent that increased funds and efficiency permit,

will increase its efforts to promote fair competition in your industry.

336 F.2d at 759. The Commission had already settled the policy issues, and had already determined what the practices of some of the companies named were and that those practices were in violation of the law. One need not read this statement to say more than that the Commission has found certain practices to be illegal in a series of cases; some cases, however, remain to be decided. The court found in it a promise to convict Texaco-not only if its practices proved to be the same (which could hardly have been objectionable), but in any event.

Judge Washington, concurring, recognized this problem, but believed the mention of Texaco $b y$ name (an element missing in Cinderella) would make it appear to a disinterested observer that Chairman Dixon had in fact prejudged its particular guilt. Once having publicly made a statement "apparently inconsistent with an ability to judge the facts fairly," 336 F.2d at 764 (emphasis added), the Commissioner could not restore his capacity to sit by protesting his openmindedness. The question is one of appearances, not actualities; and in Judge Washington's eyes, at least, that appearance arose from Chairman Dixon's choice of forum as much as his words. See Note, Administrative Law, Restraint of Trade, 78 Harv. L. Rev. 658 (1965).

118. One impartial observer, noting the repeated appearance of Chairman Dixon in these cases, explains them as the product of an unjustified "degree of personal involvement manifested by Dixon. That the result in these two cases depended so much on [his] personality . . . can be seen from other cases in which a reviewing court was not prepared to assume that prior public statements of an official would preclude him from carrying out his public duty." G. Flick, Natural Justice 128, $129 \&$ n.68 (1979), citing Cement Institute; National Lawyers Guild v. Brownell, 225 F.2d 552 (D.C. Cir. 1955); and Skelly Oil Co. v. Federal Power Comm'n, 375 F.2d 6 (10th Cir. 1967), modified on other grounds sub nom. Permian Basin Area Rate Cases, 390 U.S. 747 (1968). Kennecott Copper Co. v. FTC, 467 F.2d 67 (10th Cir. 1972), might also have been cited.

119. The Cinderella opinion marked the second effort by the defendant in the Commission action to raise prejudgment issues. The first had been brought on account of a Commission press release alerting the public to Cinderella's "suspected violations" of the FTC Act; on March 12, 1968, the court of appeals upheld the Commission, specifically remarking on the factual (not inflammatory) character of the press release and its recognition that guilt had not yet been established. FTC v. Cinderella Career \& Finishing Schools, Inc., 404 F.2d 1308 (D.C. Cir. 1968). Chairman Dixon's speech, the Cinderella II court rather pointedly notes, was made just three days later. It must have seemed to the court as if he were deliberately flouting the balance it had sought to achieve between the administrative practice (unusual to a judge) and the demands of fairness.

120. When judges have disqualified other judges for excessive commitment, it has often been in such terms as "A judge best serves the administration of justice by remaining detached from the conflict between the parties." Reserve Mining Co. v. Lord, 529 F.2d 181, 186 (8th Cir. 1976). One cannot easily substitute "administrator" for "judge" in that sentence, especially regarding policies or disputes that must be managed over time. 
trators combine these functions; the perceived potential for abuse and onesidedness may dispose some judges to find factual, personal incapacity to adjudicate in blunt talk alone, wholly in the absence of outside, unofficial, or irrational influence.

However one may react to these speculations, it is apparent that the Texaco-Cinderella formulation does not fairly capture the ruling cases. ${ }^{121}$ It is far too broad. In Cement Institute, in Pangburn, and in Withrow, the agency had "in some measure adjudged the facts as well as the law." Perhaps one could argue that in Cement Institute the facts adjudged were legislative rather than adjudicative in character - that no particular judgment about the behavior of any specific party was made; ${ }^{122}$ but the prejudged facts of Pangburn and Withrow plainly were case- and party-unique. What was missing from those cases but present in Chairman Dixon's speeches (at least in the eyes of the reviewing courts), was the irrational aggressiveness of personal commitment, a commitment making level-headed second thoughts appear too remote a possibility for fairness. Commitment, rather than exposure to facts or the exercise of judgment respecting them, appears in fact to have been the key.

The third of the influential court of appeals cases, Pillsbury v. FTC, ${ }^{123}$ also involved an FTC chairman - in this instance Chairman Howrey - and the spectre of personal commitment. Chairman Howrey had been called before a Senate committee to answer questions about FTC policy in interpreting section 7 of the Clayton Act ${ }^{124}$ - a common enough occurrence, and clearly part of his official function. The Senators' questioning forcefully and repeatedly criticized an interlocutory legal conclusion the Commission had earlier reached in an adjudication involving Pillsbury pending before an FTC hearing examiner at the time of the Senate hearings. The Senators favored an approach more adverse to Pillsbury's interests. Chairman Howrey defended the Commission's legal conclusions gamely for a while. Then, after he had been accused by a Senator of having "done some damage to [his] judicial position" by joining in an Attorney General's committee's report on some of these questions, Chairman Howrey abruptly announced his withdrawal from the Pillsbury case, because "the question you are asking . . . is a much greater challenge to judicial processes, because I am sitting as a quasi-judicial officer in that case." ${ }^{125}$ Chairman Howrey was soon off the Commission, but several others who had been in the Senate hearing room

121. Judge Tamm is at pains in his opinion for the majority in $A N A$, not once but twice, to explain Cinderella - a case in which " a person fac[ed] administrative prosecution for past behavior" - as involving "specific" reference to the adjudication pending and prejudgment of "precise factual issues." Slip op. at 19. Whether or not this accurately describes the case as it was, the characterization suggests a limited future for the formula even for adjudicatory disqualification.

122. This distinction is made by the majority opinions in $A N A$, slip op. at 38 (Tamm, J.) and 5 (Leventhal, J., concurring), and by Judge Washington in his Texaco concurrence, 336 F.2d at 764 n.6.

123. 354 F.2d 952 (5th Cir. 1966).

124. 15 U.S.C. $\$ 18$ (1976).

125. 354 F.2d at 961 . At the time of this inquest, Chairman Howrey is said already to have informed the White House of his intention to resign; in this context, his "withdrawal" from the case may have the guise of tactics more than injured judicial mien. 
with him were commissioners five years later when the Commission decided against Pillsbury, maintaining again the legal theory the Senators had so vigorously challenged. Having been exposed to that pressure, the Fifth Circuit ruled, these commissioners should have disqualified themselves:

To subject an administrator to a searching examination as to how and why he reached his decision in a case still pending before him, and to criticize him for reaching the "wrong" decision, as the Senate subcommittee did in this case, sacrifices the appearance of impartiality - the sine qua non of American judicial justice-in favor of some short-run notions regarding the Congressional intent underlying an amendment to a statute, unfettered administration of which was committed by Congress to the Federal Trade Commission (See 15 U.S.C.A. $\S 21) .{ }^{126}$

Here again, one senses that the court may have overreacted. Had the Pillsbury Corporation not been named, the committee would surely have been permitted to inquire into the important legal interpretation at issue. Like Chairman Dixon's speeches, Chairman Howrey's appearance was a necessary and legitimate official function, but one not shared by judges. In refusing to recognize these functions, or in imposing strict standards of decorum, the appeals courts were to some degree denying validity to the presumption repeatedly relied upon by the Supreme Court, that public officers will be able to carry out all their official functions in a manner consistent with fairness. It is at least doubtful whether the Supreme Court could make the judgment "that, under a realistic appraisal of psychological tendencies and human weakness," combining adjudicative with public or congressional discussions of agency business "poses such a risk of actual bias or prejudgment that the practice must be forbidden if the guarantee of due process is to be adequately implemented." ${ }^{127}$ The courts of appeals, closer to the agencies and (perhaps for that reason) more skeptical of their performance, seem quicker to conclude that a decisionmaker has compromised his integrity.

Each of the cases discussed arose in a strictly accusatory context, the setting in which concern for fairness, and adjudicatory objectivity as an element of fairness, has always been strongest. Given that context and appropriate sensitivity to the distinction between individual circumstances and general policy, between what Cinderella in particular may have done and career school practices generally, the rules fashioned by the courts of appeals match general expectations about the demands of justice and cause no substantial inconvenience to agency functioning. It is significant that the results of these cases appear not to be significantly galling to-and, indeed, are in some respects welcomed by - the agencies whose behavior they control. Agencies are concerned with public perceptions of their credibility and fairness, and commissioners can find ways of talking about policy to the public or Congress without having to discuss the

126. Id. at 964 (footnote omitted).

127. Withrow v. Larkin, 421 U.S. 35, 47 (1975), citing Cement Institute. 
details of pending cases. The occasional "allegedly" or "our staff has asserted that" does not significantly interfere with any discussion a commissioner might wish to have, and contributes to the public's sense of his judiciousness. ${ }^{128}$ The ability to warn Senator Smith's staff before a hearing to stay away from cases $X$ or $Y$, now pending in litigation, offers, from the agency's view, welcome protection. No central function is threatened, and in the context of adjudication in on-the-record accusatory cases, the core values of impartiality are at stake. If the courts of appeals have been inattentive to differences between administrative and judicial functions in this context, the negative impacts of the resulting "judicialization" are slight, and the gains in apparent fairness to a public used to the judicial model may be substantial. In the setting in which, under the Constitution and the APA, administrative and judicial functions most closely merge, a hairtrigger response to apparent impropriety is acceptable.

\section{CONSTRAints ON POlicymakers: Disqualification FOR "BIAS" OR "ANIMUS" IN RULEMAKING}

The introduction to this Article suggested some of the special characteristics of agency rulemaking (or, more broadly, policymaking) complicating any inquiry into the question which individuals should not be permitted to participate in rulemaking. The intervening pages have sketched the two obvious models from which reasoning might be essayed, and the possible lines of extension of one, conflict of interest regulation, to rulemaking. What follows examines the possible application in the rulemaking context of prejudgment standards, and the somewhat distinct issue of "animus."

As already remarked, no agency currently provides in its regulations for disqualification in rulemaking for other than conflicts of interest. An explanation is provided by the reasons for limiting even conflict of interest analysis, and pointedly expressed in the agency responses to the ACUS survey. While private claims to "impartiality" are not thought to be as large in rulemaking as in adjudication - particular factfinding is not often involved, the stakes for particular individuals may often be less, and in any event the stakes are multidimensional - the chief reasons stated have to do with institutional functioning:

"In policy-making or informal rulemaking . . . , adoption of disqualification rules ... could inhibit the appointment and functioning of extremely qualified individuals whose very views were significant in their consideration for appointments. . . ." ${ }^{129}$

Disqualification "would be contrary to one of the main reasons for having agencies in the first place - namely, to create a storehouse of information that can be brought to bear on regulatory decisions in a flexible manner." 130

128. See Kennecott Copper Co. v. FTC, 467 F.2d 67 (10th Cir. 1972).

129. Letter of Dep't of Agriculture to Richard K. Berg, Executive Sec'y, ACUS, dated Aug. 7, 1979 , at 2 .

130. Letter of Environmental Protection Agency, dated June 25, 1979, at 1. 
Other "procedural mechanisms ... promote intellectual honesty and the appearance of fairness" - full notice, detailed explanation, recording of outside contacts, full internal consultations among numerous employees, etc. "A rule requiring disqualification ... might force the agency to exclude its senior officials from the earliest periods of the decisionmaking process," yet such officials naturally must respond to newly discovered concerns, to the public and to Congress, and that response requires "detailed knowledge" and "candid discussion." 131

"[A]gency decision-makers should be encouraged to discuss the policy issues before their agency with the public and to give their views on those issues." The possibility of disqualification "will discourage [such discussions] and thus injure the public's ability to understand (and influence) agency policy-making decisions.

"Finally, the President ... [a]s the nation's highest elected official ... may properly ... select nominees who are predisposed to carry out the policies of his administration ... . To bar Members from participating ... because of their policy preferences would frustrate the President's authority. . . .' ${ }^{132}$

Some scope for disqualification nonetheless appears to be recognized, even though not formally provided for. For example, many agencies stated that a decisionmaker personally unable to accept and respond to public input during the public processes of rulemaking would appropriately be subject to disqualification. Seven independent agencies submitted an amicus curiae brief at the court of appeals level in the $A N A$ litigation, in which they put forward the proposition, adopted in haec verba by the court, that disqualification should occur "when there has been a clear and convincing showing that the agency member has an unalterably closed mind on matters critical to the disposition of the proceeding." 133 Responses to the ACUS survey suggested a widespread disposition to apply a similar standard-excluding the closed-minded, but with care not to discourage the public expression, even strongly, of "preliminary views.", 134 Chilling of that dialogue was frequently identified as a major negative consequence of a disqualification standard, and one therefore to be guarded against in its formulation.

131. Letter of the Food \& Drug Division, Office of General Counsel of Dep't of HEW, dated July 24,1979 , at $3-4$.

132. Letter from Philip J. Bakes, Jr., General Counsel, CAB, dated Aug. 16, 1979, at 2.

133. Brief for Independent Regulatory Agencies as Amici Curiae at 14-15.

134. "[I]ntemperate public statements," indicating that one is "not prepared to approach regulatory decisions with a mind open to persuasion," arguably disqualify - but on account of "personal attitudes of the decisionmaker in question, not . . . what he was exposed to by way of information." Letter of EPA, supra note 130.

The Department of Transportation referred to "personal hostility" or unalterable predisposition, as distinct from knowledgeability. "The question should be whether the degree of disposition precludes the decisionmakers from being objective." Individual responses from the agencies signatory to the amicus brief reflected a similar view. 
The response of the Consumer Product Safety Commission suggested a related proposition, analogous to the rule that a judge should not participate in appellate review of his own trial decision. An administrator, the response suggests, is more capable of reevaluating a judgment he has previously made but identified as tentative - a proposed rule, a determination of probable cause, or the like - than a judgment taken with an expectation of finality, and for this reason should avoid external activities in which "final" judgment on matters of interest to the Commission may be called for. ${ }^{135}$ This consideration appears to be reflected in the Conference's recent recommendations on Federal Agency Interaction with Private Standard-Setting Organizations in Health and Safety Regulation. ${ }^{136}$ Standard-setting organizations produce rule-like definitions of health and safety standards which may also be the subject of federal rulemaking; the Conference believed that agency participation in standard setting was desirable, but that this participation had to be shielded from the fact or appearance of agency commitment to the standards set. Thus, it reasoned, agency representatives should have no authority to vote in the standard-setting organization or bind the agency to its conclusions; within the agency itself the representatives should exercise no decisional authority (as distinct from providing information and advice) save in cases of necessity. The CPSC has adopted more far-reaching regulations insulating participants in standard-setting from decisional responsibility in rulemaking. ${ }^{137}$

The Conference recommendation and CPSC rules are, in effect, limited disqualification standards. Certain agency officials responsible for rulemaking are instructed not to engage in other, parallel behavior thought to compromise either the fact or the appearance of their objectivity. Conference consideration of this aspect of the recommendation was apparently controversial, some believing that at least unconscious cooption or commitment would result if the rulemaker were permitted to take part in the intense consideration preceding adoption of a voluntary standard; others, that any disqualification regime would intrude on institutional decision processes, rendering them less expert by depriving the agency of

135. A similar distinction appears to have been drawn by the Supreme Court in Withrow v. Larkin, 421 U.S. $35,58 \mathrm{n} .25$ (1975). It may rest more on a right to have review be independent if review is provided than on general propositions about the psychological readiness of the decisionmaker to reconsider. When a judge is instructed by an appellate tribunal to retry a case, or decides himself to do so on the basis of post-verdict motions, we do not regard his objectivity in the second trial as having been compromised by his participation in the first-even though he regarded his first decision when reached as "final" in the usual sense.

136. ACUS Recommendation 78-4, I C.F.R. $\$ 305.78-4$ (1980). The supporting study, Hamilton, The Role of Nongovernmental Standards in the Development of Mandatory Federal Standards Affecting Safety or Health, 56 Tex. L. Rev. 1329 (1978), discusses government employee participation at $1466-73$.

137. 16 C.F.R. Part 1031 (1980). The stated concern of the regulations is with avoiding the risk of "losing . . . independence or impartiality." They preclude a designated group of high level officials who "make the final decision [within CPSC] or ... advise those who make [it]" from any participation in nongovernmental standard-setting agencies; permit another designated group whose members "develop the final recommendation" to participate only with case-by-case clearance; and allow other employees to participate only on stated conditions - that they not lead, that their participation not be approved in advance and reported upon afterwards, that meetings be public, and so forth. Other agency practices, as of 1977, are described in Hamilton, supra note 136, at 1467-69. 
its best-informed personnel and disturbing the informal flow of ideas. Similar lines of controversy can be expected as a result of the study from which this Article is derived. ${ }^{138}$

The resolution reached suggests two judgments restricting disqualification, from which some instruction may possibly be taken. The first is that disqualification need not occur if "the agency has no other personnel with the requisite knowledge and expertise"; the second, that it extends only to decision making and not to "providing information and advice."

The first of these judgments is far more forgiving than the "doctrine of necessity" sometimes applicable in the adjudicatory context. In adjudication, that there is no equally qualified substitute decider is not enough to invoke necessity; a substitute must be wholly unavailable. In the consultant's report leading to the Conference recommendation, the view had been strongly expressed that representatives to standard-setting organizations be drawn from no higher than middle level employees, "[t]o preserve the appearance of agency independence and objectivity." ${ }_{139}$ This limitation was not expressed in the Conference recommendation, apparently on the understanding that high level participation would sometimes be desirable. Thus, while the recommendation implies that high level participation should ordinarily be avoided, its disqualification standard is a weak one, rather easily overcome by the agency's needs.

The second judgment, that the agency representative to the standard setter may continue to provide information and advice within the agency, is also more permissive than adjudicatory disqualification. ${ }^{140}$ As separation of functions and ex parte contact rules vividly show, restrictions on informing and advising by "biased" participants are regarded as central to the assurance of objectivity in adjudication. The recommended measure here serves more to create a buffer than to exclude the decisionmakers from the processes, influences, and results of the

138. The dispute is itself unlikely to prove objectively resolvable; our knowledge of human psychology does not extend to quantifying the degrees of commitment or cooption that result from deciding that an issue is important enough to be studied, from participating in the formulation of proposal drafts on the basis of initial information and views, or from taking part as an agency representative in the compromise process of an external group facing similar issues. However, no agency and no court currently regards the first two activities as disqualifying; they are a regular part of the activity of agency rulemakers. The third activity is, of course, the subject of the conference recommendation.

139. Hamilton, supra note 136 , at 1472 .

140. A similar accommodation appears in the recent Conference recommendation on reimbursement of participants' expenses by the FTC, ACUS Recommendation 79-5, 45 Fed. Reg. 2307 (1980) (to be codified at 1 C.F.R. $\$ 305.79-5$ ). The staff engaged in developing proposed rules, the Conference's consultant concluded, often acquired "strong feelings about the need for regulation and the shape that rule provisions ought to take." B. Boyer, Expense-Reimbursing Public Participants in Administrative Rulemaking: The Federal Trade Commission Experience 79-80 (Draft 1979). The resulting "color" on the staff's funding recommendations strongly supports the FTC's judgment, approved by the Conference, to have others make the funding decision. At the same time, their advice is essential for efficient assessment of the applicant's potential contribution to a complex record; and public disclosure of that advice (with possible ensuing controversies) presents costs which, it seems to have been agreed, outweigh any benefits of publicity. Thus, the Conference has recommended that rulemaking staff be permitted to advise but not decide about reimbursement issues; "wherever feasible," those who do decide should also be given access to experts outside the offices directly responsible for the rulemaking. 
voluntary standard-setting process. The buffer is useful in preserving apparent freedom of action and apparent objectivity; but the judgment creating it (like the judgments confining the reach of separation of functions and ex parte contact constraints) is a limited one, sensitive to the needs of an institutional decisional process.

\section{A. Bias or Prejudgment-Association of National Advertisers v. FTC}

The procedural context of the $A N A$ case, ${ }^{141}$ described briefly in the introduction, made it a relatively strong case for considering rulemaking disqualification. Although no statutory or regulatory provision explicitly requires impartiality, Congress has provided in the Magnuson-Moss Act a statutory regime with many of the trappings of trial procedure. For Judge Gesell in the district court the syllogism was simple. On-the-record proceedings involving adversary, oral procedures ordinarily require impartiality in the decisionmaker. Magnuson-Moss Act procedures envision adversary, on-the-record proceedings as to certain facts. Therefore, participants in Magnuson-Moss Act rulemakings are entitled to a decisionmaker impartial as to those facts. ${ }^{142}$ Whether or not one agrees that the issue here is as simple as Judge Gesell found it, the relative strength of the case for a disqualification regime should be apparent.

This line of argument depends for its strength on the presence of a requirement for on-the-record adversariness, procedures that make objectivity important. As has already been remarked, ${ }^{143}$ nothing in section 553 of the APA or general agency practice under that provision suggests a basis for such an argument respecting rulemaking generally. And the majority in the court of appeals on review of $A N A$ found that, even in the special statutory circumstances of Magnuson-Moss, the characteristics of rulemaking required disqualification regimes to be significantly more limited than those applying in adjudication. It agreed that an impartial decisionmaker was required. But the differing nature of factual issues in rulemaking and adjudications, the impossibility of separating fact from policy in the former setting, and the administrator's corresponding imperative to form and express his views at an early stage, led it to eschew "formulation of a disqualification standard that impinges on the political process." ${ }^{144}$ Judge Tamm wrote for himself and Judge Leventhal that an agency member may be disqualified (in rulemaking) "only when there has been a clear and convincing showing that [he] has an unalterably closed mind on matters critical to the disposition of the proceeding." ${ }^{145}$ On the facts, he found, that test was not met. Judge MacKinnon, in dissent, found this test too strong a formulation-a fence "horse high, pig tight and bull strong." ${ }^{146}$ Drawing what he found to be appropriate inferences from the FTC's special rulemaking

141. No. $79-1117$ (D.C. Cir. Dec. 27, 1979), cert. denied, 48 U.S.L.W. 3820 (1980).

142. 460 F. Supp. 996 (D.D.C. 1978).

143. See text accompanying notes $91-93$ supra.

144. $A N A$, slip op. at 48

145. Id. at 38 .

146. Id. at 15 (MacKinnon, J., dissenting in part and concurring in part). 
procedures, he concluded that partiality could be established by a preponderant showing of substantial prejudgment on any critical fact; that showing, he argued at length, had been made.

1. A Constitutional Requirement of Openmindedness in Rulemaking? Recognizing that statutes like those involved in $A N A$ might present the strongest case for disqualification regimes, one may nonetheless start with the issue whether due process requires impartiality as to fact (as distinct from freedom from disabling conflicts of interests) in all informal rulemaking. A more general premise than Judge Gesell employed in his reasoning, one suggesting extension of disqualification standards to less formal rulemakings, would be that constitutional due process requires impartiality (however defined) in the decisionmaker in any rulemaking likely to have significant adverse impacts on an individual. Under this premise, the $A N A$ dispute would not turn only on the meaning of the Magnuson-Moss Act, and disqualification might be an appropriate issue in any significant APA rulemaking.

A due process argument for disqualification in rulemaking must begin with recognition of the very limited scope the Supreme Court has given "prejudgment" as a due process issue in cases of adjudication, suggesting as a test even in that context whether the decisionmaker's mind was "irrevocably closed" or subject to a "personal" (as distinct from official) psychological commitment. ${ }^{147}$ Beyond that, the Court has given little indication that it regards due process as a significant issue for any purpose in the rulemaking context. While legislative procedure, as distinct from legislative result, might seem fairly within the reach of due process concerns, ${ }^{148}$ the Supreme Court appears committed to Justice Holmes's classic proposition that in policy formation, citizen interests are protected "in the only way they can be in a complex society, by [the individual's] power, immediate or remote, over those who make the rule." ${ }^{149}$ Any exceptions, it has supposed, would be "extremely rare," ${ }^{150}$ as where the determinations are essentially individual in character, affecting particular persons in an exceptional way; ${ }^{151}$ they would not occur in the context of general rulemaking. ${ }^{152}$

In his thoughtful analysis of the "due process of lawmaking," ${ }^{153}$ Professor (now Justice) Hans Linde drew a distinction between legislation and rulemaking

147. See text accompanying notes $94-99$ supra.

148. The Supreme Court's analyses of the circumstances in which process is constitutionally due have stressed the need to show a deprivation of "life, liberty or property," see, e.g., Bishop v. Wood, 426 U.S. 341 (1976); Arnett v. Kennedy, 416 U.S. 134 (1974); Board of Regents of State Colleges v. Roth, 408 U.S. 564 (1972). It is regarded as generally inappropriate to examine a statute for that effect; such an analysis evokes the dubious realm of substantive due process. Rules would appear to present a like situation.

149. Bi-Metallic Inv. Co. v. State Bd. of Equalization, 239 U.S. 441, 445 (1915) (emphasis added). See also Vermont Yankee Nuclear Power Corp. v. Natural Resources Defense Council, Inc. 435 U.S. 519, 542 (1978).

150. 435 U.S. at 524 . 1977).

151. Id. at 542. See also Action for Children's Television v. FCC, 564 F.2d 458 (D.C. Cir.

152. 435 U.S. at 542 n. 16.

153. Linde, Due Process of Lawmaking, 55 Neb. L. Rev. 197 (1976). 
which could further the "fairness" claim, and thus diminish the force of Holmes's aphorism. "[P]olicy-makers . . . limited to prescribed aims," as agency rulemakers are, may be distinguished theoretically from legislators "free to pursue any aim of their own choice." ${ }^{154}$ The former, he asserted, have a constitutional obligation of explanation or justification not shared by general purpose legislative bodies - a "duty to defend the rationality of a decision," to use "the methods of rational policy analysis" to relate the action taken to "a goal within the scope of [their] assignment." ${ }^{155}$ Acceptance of this distinction, not yet to be found in Supreme Court opinions, would give constitutional dimensions to whatever procedures may be inherently required for "rational policy analysis." 156

The judges of the court of appeals seem to have assumed that "due process" was implicated in their judgment, but without explaining how they reached this result. ${ }^{157}$ Although the majority and minority opinions do not rely on Professor Linde's analysis, one aspect of their disagreement suggests parallels to his distinction between general-purpose and special-purpose rulemakers. The majority draws heavily on an analogy to legislative action in reaching its conclusion that "due process" requires little independent of what Congress may have chosen to require; ${ }^{158}$ elsewhere the majority stresses the necessarily political character of general rulemaking and the need to avoid legal rules that would inhibit its operation. ${ }^{159}$ For Judge MacKinnon, on the other hand, the analogy to a legislature is inapt: legislative bodies are controlled by the diversity of their membership and direct electoral responsibilities; agencies may have some political aspects, but judicial enforcement of principles of rational decisionmaking (which in

154. Id. at 229.

155. Id. at $225-30$

156. The argument for the Linde approach might seem particularly strong where the rulemaking will resolve technological or other issues of a specific and factual, more than judgmental, character-especially if those issues would otherwise be subject to resolution in adjudicatory proceedings. The question then would be whether the presence of prejudgment, as distinct from financial self-interest, is inconsistent with those procedures.

Professor Linde's analysis and some existing case law suggest that serving financial self-interest may be constitutionally disqualifying in this setting. Id. at 249-50, citing McNamara v. Borough of Saddle River, 60 N.J. Super. 367, 158 A.2d 722 (1960); see also State Bd. of Dry Cleaners v. Thrift-D-Lux Cleaners, Inc., 40 Cal. 2d 436, 440-46, 254 P.2d 29, $31-34$ (1953). The Supreme Court's decision in Friedman v. Rogers, 440 U.S. 1, 18 (1979), on the other hand, unanimously denied the existence of any "constitutional right to be regulated by a Board that is sympathetic to [that is, not structured to be financially biased against] the commercial practice of optometry," and limited the due process claim for disqualification for financial interest specially to the setting of a "disciplinary proceeding." No basis for claiming disqualification for factual prejudgment, a weaker claim than financial self-interest, appears.

157. $A N A$, slip op. at 47 (Tamm, J.), 3 (Leventhal, J., concurring). The references to "fundamental notions of fairness" in other D.C. Circuit rulemaking review opinions are equally without precedential support, and tend to involve determinations of limited and exceptional impact. E.g., Home Box Office, Inc. v. FCC, 567 F.2d 9, 57 (D.C. Cir.), cert. denied, 434 U.S. 829 (1977). Compare Action for Children's Television v. FCC, 564 F.2d 458 (D.C. Cir. 1977).

158. $A N A$, slip op. at 27-28. "No court to our knowledge has imposed procedural requirements on a legislature before it may act. Indeed, any suggestion that congressmen may not prejudge factual and policy issues is fanciful." Id. See Townsend v. Yeomans, 301 U.S. 441, 451 (1937). Compare Hennessy v. NCAA, 564 F.2d 1136 (5th Cir. 1977).

159. $A N A$, slip op. at $34-35,48$. 
this instance include protections against prejudgment) is also fully appropriate. ${ }^{160}$ Whether on his analysis these principles emerge from the Constitution independent of statute is unclear, but perhaps not important to resolve.

This is, of course, hardly the first instance when confusion or controversy has clouded judicial determinations of what "fairness" requires. The vigorous and sometimes bitter debates within the Vinson and Warren Courts regarding "incorporation" of Bill of Rights liberties into the fourteenth amendment by interpretation of the due process clause pitted proponents of informed judicial intuition, on the one hand, against those who insisted that responsible judicial action could be based only on concrete, external sources. ${ }^{161}$ If explicit standards are to be the guide, none exist in the Constitution, in the regular practice of legislatures or the case law respecting it, or indeed in the prior case law of administrative procedure. The $A N A$ majority explicitly notes this absence of external standards, even as it proceeds to "determin[e] the due process standards applicable." 162 If, on the other hand, judges are to rely on informed judicial intuition-and in the administrative law context there may be no realistic alternative ${ }^{163}$ - the risks of that approach have led judges using it to seek "to eliminate the purely personal preference," by "respectful deference" to the views of other tribunals or the legislature and by deriving conclusions from judgments already made by others rather than by "making new moral choices." 164 As has been seen, external judgments about the requirements of fairness in rulemaking are few, and those that exist are extremely permissive. ${ }^{165}$ Should a statute be enacted explicitly denying any opportunity to claim disqualification for prejudgment by a rulemaker, it would surely withstand constitutional attack. ${ }^{166}$ Despite the trappings of constitutional language and evi-

160. Id. at 26-29.

161. See, e.g., Duncan v. Louisiana, 391 U.S. 145 (1968); Rochin v. California, 342 U.S. 165 (1952); Adamson v. California, 332 U.S. 46 (1947). To my colleague Benno Schmidt, Jr., I owe the observation that this dispute should not be understood merely as one over judicial function in the determination of procedural issues; it occurred in the wake of the substantive due process excesses of the 1920's and 1930's, and each side might have believed its approach better constituted to avoiding a renewal of judicial aggrandizement. See generally Linde, supra note 153.

162. $A N A$, slip op. at $27-28$.

163. That understanding appears to be reflected in the Court's often quoted observation, in Cafeteria Workers Local 473 v. McElroy, 367 U.S. 886, 895 (1961), that " $[t]$ he very nature of due process negates any concept of inflexible procedures universally applicable to every imaginable situation."

164. G. Gunther, Constitutional Law 523 (9th ed. 1975), quoting Kadish, Methodology and Criteria in Due Process Adjudication-A Survey and Criticism, 66 Yale L.J. 319 (1957). Certainly in the incorporation debate those who pursued the more subjective, "civilized standards of decency" approach demonstrated by the results they reached substantial deference to the procedural assessments of others; procedural activism is associated with the pro-incorporation side of the debate. The Court has often stressed deference to congressional judgment about administrative procedure, using those judgments as a model for its own determinations as well as generally refusing to disturb them under challenge. Compare Wong Yang Sung v. McGrath, 339 U.S. 33, modified, 339 U.S. 908 (1950), with Marcello v. Bonds, 349 U.S. 302 (1955). See also Vermont Yankee Nuclear Power Corp. v. Natural Resources Defense Council, Inc., 435 U.S. 519 (1978); Goldberg v. Kelly, 397 U.S. 254 (1970).

165. See note 156 supra.

166. See Friedman v. Rogers, 440 U.S. 1 (1979), discussed in note 156 supra. 
dent concern of the judges for "fairness," the decision in $A N A$ is best understood as a statutory holding only.

2. Inferring Prejudgment Standards from Procedural Choices. Although it was influenced by intuitive notions of fairness, the court of appeals debate chiefly concerned how Congress's procedural choices in the Magnuson-Moss Act bore on the disqualification issue. Several propositions appear to have been agreed upon by all judges: first, that the disqualification question had not been explicitly faced in Congress, for any specific congressional resolution would have been controlling; second, that some standard of disqualification should be inferred from the Magnuson-Moss Act procedures; third, that this standard had particular importance for those factual issues that were to be referred for decision on the record, following trial-type procedure; and finally, that the Cinderella test for adjudication, whether "a disinterested observer may conclude that [he] has in some measure adjudged the facts . . . in advance of hearing," was inapplicable. Even the dissent would have required "the moving party [to] show by a preponderance of the evidence that the decisionmaker could not participate fairly in the formulation of the rule because of substantial bias or prejudgment on any critical fact that must be resolved in such formulation." ${ }_{167}$ The stressed words indicate the areas of disagreement with the majority, ${ }^{168}$ to which we shortly return; for the moment we focus on the areas of agreement.

a. Matters Not in Dispute-A Limited Standard for Special Circumstances. Majority and dissent agreed on the proposition, which also characterizes current congressional efforts at general administrative reform, that prejudgment is an appropriate inquiry for-but only for-issues requiring the procedures of trial for resolution. Any general consideration of extending the use of "modified," "general," or "hybrid" procedures will inevitably involve consideration of the extent to which the objectivity of the decisionmaker must be assured. To gauge by currently pending reform proposals, moreover, any congressional action will impose a measure of disqualification in proceedings conducted in some measure on the record through trial-type procedures. ${ }^{169}$ In contrast with the APA separation of functions provisions discussed above,${ }^{170}$ all the pending proposals assume that some internal separation of functions should be enforced, that to that extent the influence of prejudgment or bias is to be avoided. ${ }^{171}$ Such protections read-

167. $A N A$, slip op. at 37 (MacKinnon, J., dissenting in part and concurring in part) (emphasis added).

168. See text accompanying note 188 infra.

169. Debate over the extent to which objectivity is to be required has been most explicit in the separation of functions context, where proposals vary from extension of the current standards of $\S$ 554(d), not now applicable to formal rulemaking, see S. 262, 96th Cong., 1st Sess. § 202(c) (1979), to segregation from the decisionmaker only of those agency employees most immediately involved in presenting the agency's "case," S. 2147, 96th Cong., 1st Sess. (1979); H.R. 3263, 96th Cong., 1st Sess. $§ 202$ (1979).

170. See text accompanying note 92 supra.

171. The section-by-section analysis accompanying S. Doc. No. 2147, supra note 169, states that "trial staff" are separated "because this is a job that can generally only be done well by people who take an adversarial position toward the issues," an attitude fairly regarded as disqualifying in the committee's view. Wider disqualification, however, would "affirmatively diminish the quality of agency decisions" by restricting an agency's use of its expertise. 125 Cong. Rec. S19061 (daily ed. 
ily imply other protections for impartiality as to fact. By way of contrast, no serious legislative consideration is being given to extending separation of function or prejudgment standards to settings in which a decision does not occur "on the record" in some measure. If legislators are satisfied to have free discussion within the agency, no matter how committed the discussants, it is hard to infer significant concern with protecting objectivity.

In ordinary rulemaking, there is neither a statutorily defined record nor any indication that rulemaking is to be confined to one or assessed by one. Participants' procedural rights are rights of access, not rebuttal, and consequently the pre-existence of a state of mind that would effectively impede one's ability to rebut is an irrelevancy. If, however, Congress has adopted procedures defining a record, requiring the results of rulemaking to be supported by "substantial evidence," and, fairly read, recognizing an interest in rebuttal, then concern with objectivity is a fair inference.

The interest in an opportunity to know, confront, and oppose or rebut others' views is the central factor in this aspect of the analysis. Traditionally, that has not been viewed as a feature of informal rulemaking. The APA states no requirement that the agency expose its data base. If a commenter chooses to submit its views at the last moment, others, however appalled, acquire no right to force agency consideration of a reply. Of course, the conclusion reached will vary with changes in the procedures employed. If an agency voluntarily conducts rulemaking in a manner suggesting acceptance of the desirability of confrontation as to some issues, application of disqualification standards may be implied. Recent case law developments, notably in the D.C. Circuit, suggest increasing acceptance of the view that an opportunity for "adversarial comment" is an inherent part of section 553 procedure. ${ }^{172}$ Although the Administrative Conference has rejected that view as "converting rulemaking proceedings into a species of adjudication ... neither practicable nor desirable," ${ }^{173}$ its influence appears to be growing. To the extent effective reply or adversarial critique is recognized as a valid procedural claim in informal rulemaking, a right to objectivity in the decisionmaker according to some standard is likely to follow.

Even in the setting in which some measure of impartiality will be required, the $A N A$ judges all agreed that the prejudgment inquiry should be more limited than would be the case for adjudication. None of the congressional proposals or discussions indicate a different judgment. The factors that underlie this apparent judicial and legislative agreement are those already suggested in the introductory material. ${ }^{174}$

Dec. 18, 1979). While trial staff "bias" may not be inevitable, it should not be surprising; the Conference study of FTC rulemaking under the Magnuson-Moss Act - which contains no comparable separation of functions provision-finds that it has been generated in that particular setting. See also note 19 supra.

172. Home Box Office, Inc. v. FCC, 567 F.2d 9, 55 (D.C. Cir.), cert. denied, 434 U.S. 829 (1977); Portland Cement Ass'n v. Ruckelshaus, 486 F.2d 375, 393-94 (D.C. Cir. 1973), cert. denied, 417 U.S. 921 (1974).

173. ACUS Recommendation 77-3, I C.F.R. $\S 305.77-3$ (1980).

174. See text accompanying notes 16-25, 129-32 supra. 
Ordinary rulemaking is impossible without some prejudgment by the rulemaker, and modern trends emphasize that requirement. A rulemaker must form a preliminary view if he is to make a proposal; in Judge Leventhal's words, "one cannot even conceive of an agency conducting a rulemaking proceeding unless it had delved into the subject sufficiently to become concerned that there was an evil or abuse that required regulatory response." 175 The increasing insistence that administrators take formal responsibility for the formulation of agency policy, ${ }^{176}$ that rulemaking proposals be published with elaborate analyses of possible economic and/or environmental impacts and realistic alternatives, and that the proposals also reveal the data base on which the agency has acted-all emphasize the inevitability of prejudgment. Even in the past, significant proposals for rulemaking were rarely the unsupervised product of low-ranking officials; today it must be assumed that any significant proposal will have attracted substantial oversight - hence prejudgment - from the top.

Prejudgment is inevitable in another respect, shown by the absence of separation of functions constraints. At the staff level, no distinction is made between proponents (or, for that matter, opponents) of rulemaking and participants in it; the integration of decisional function, the institutional decisional process, is regarded as one of the strengths of rulemaking as a procedural mode. As some respondents to the ACUS survey noted, the wide range of staff officials who may participate in any given rulemaking is itself some assurance of objectivity. The point, here, however, is that there is a wide range of participation, thought to be important because of the contribution made to institutional decision; some or all of these participants will have formed prejudgments whether or not their superiors have, and they will take advocacy positions in the internal debate. It is important to note that "disqualification" would reach these concerned agency staff members as well as the commissioners themselves. The judgment not to exclude them rests on practical political assessments that it is too expensive and cumbersome to maintain agencies with multiple expert staffs; that the assistance of these experts is more essential to sound policy formation than it would be to resolving a particular dispute about the consequences to be attached to past action; that the possible influence of emotional attachment to preformed conceptions is less harmful to private interests when those conceptions concern policy matters subject to public discussion and legislative change rather than final determinations of individual guilt. The public may, of course, reassess this balance, but present judgment is that it would be a mistake to do so. All the opinions acknowledged these implications, although not focusing - as the facts did not require them to-on the consequences of applying a disqualification regime below the agency level. ${ }^{177}$

175. $A N A$, slip op. at 4 .

176. See, e.g., the requirements for executive agency rulemaking stated in Exec. Order No. 12,044, 43 Fed. Reg. 12,661 (1978)

177. E.g., $A N A$, slip op. at 35: "[A] neutral and detached adjudicator is simply an inapposite role model for an administrator who must translate broad statutory commands into concrete social policies." 
In addition to the prejudgments that rulemaking procedures require agency actors to form, other aspects of agency functioning are at least conducive to their formation. Agency heads are appointed in a political process to serve avowedly political ends, and their success is measured by their ability to carry specific desired policy into effect. They must regularly defend their programs to the White House and Congress, to regulated industry and the public. In such a setting, commitment is inevitable and desirable. Nor are outside contacts solely confrontational; interchange of information and view is a continuing necessity for any agency. The processes of acquiring information and discussing possible future directions also produce and suggest prejudgments.

The range of probable legislative and judicial agreement here is suggested by the very limited development of precedent and principle on "undue influence" and ex parte contacts, the descriptions usually made of behavior outside the agency that might be productive of disapproved prejudgments. As mentioned earlier, ${ }^{178}$ strictures against congressional interference in adjudication are generally accepted, even welcomed; suggestions of impropriety are much harder to find in the setting of policymaking. ${ }^{179}$ And while the courts and others have begun to express limited concern with ex parte contacts in rulemaking, that concern is generally conceded to be inappropriate for the time prior to notice of proposed rulemaking, when agency prejudgments will most probably be formed. ${ }^{180}$ In earlier opinions, Judge MacKinnon opposed the extension of constraints in both these contexts, protesting what he regarded as excessive interference with a properly political process; ${ }^{181}$ presumably, then, he accepts in $A N A$ the general legitimacy of political functions by agency rulemakers.

For the majority, these external political relationships were a major element contributing to selection of a disqualification standard. That standard must not "impinge[] upon the political process. An administrator's presence within an agency reflects the political judgment of the President and Senate." 182 Discussion of policy issues with industry and public, "appropriate and indeed mandatory for agency heads and staff,", 183 "would be futile . . . if the administrator could not test his own views on different audiences." 184 The majority was resolute that restrictions on ex parte contacts would not possibly apply prior to

178. See text accompanying notes $123-28$ supra.

179. In D.C. Fed'n of Civic Ass'ns v. Volpe, 459 F.2d 1231 (D.C. Cir. 1971), cert. denied, 405 U.S. 1030 (1972), the prevailing opinions were careful to state that the consideration of improper factors, rather than the making of improper approaches, was the flaw; the decision there was reached in informal adjudication, not rulemaking. Compare Texas Medical Ass'n v. Mathews, 408 F. Supp. 303 (W.D. Tex. 1976) (congressional pressure requires invalidation of rulemaking), with Florida Dep't of Health v. Califano, 449 F. Supp. 274 (N.D. Fla. 1978) (only "virulent" extrinsic pressures, involving threats of political retaliation, are objectionable).

180. Home Box Office, Inc. v. FCC, 567 F.2d 9, 57 (D.C. Cir.), cert. denied, 434 U.S. 829 (1977); see $A N A$, slip op. at 36 n.40, 44 (Tamm, J.).

181. Home Box Office, 567 F.2d at 61-64; D.C. Fed'n of Civic Ass'ns v. Volpe, 459 F.2d at 1256-62.

182. $A N A$, slip op. at 48 (Tamm, J.).

183. Id. at 4 (Leventhal, J.).

184. Id. at 38 (Tamm, J.). 
notice of rulemaking; that conclusion of course implies freedom to make contact ${ }^{185}$ and thus to reveal attitudes or entertain dialogues that to others may signal prejudgment.

At times, Judge MacKinnon's opinion appears to repudiate the majority's emphasis on the irreducibly political character of rulemaking. He views the analogy to a legislator as inappropriate and infers from the Magnuson-Moss Act a particular judgment to impose limits on political behavior by commissioners; he hints that some such limits would apply even in informal rulemaking. ${ }^{186}$ Yet Judge MacKinnon denies any intent to prohibit the free interchange of ideas with other officials or the public. "[P]ublic discussion of policy issues" is desirable, but is to be distinguished from "haranguing the public"; discussing the wisdom of various regulatory positions - acceptable behavior-is to be differentiated from loud advocacy. ${ }^{187}$ The practical workability of this distinction can be questioned. It is even more difficult to distinguish the results of performing official responsibilities from evidence of personal zeal in assessing the impact of political contacts and responsibilities than in examining the consequences of intra-agency rulemaking practices. The distinction thus invites doubt, litigation, and variable outcome. If one accepts the distinction, however, the result can fairly be characterized as substantial agreement by Judge MacKinnon with the majority's views on the appropriateness of political contacts in rulemaking.

b. Matters in Dispute - What Standard Is to Apply to Which Issues? The disagreements in the court of appeals principally focused on what standard of disqualification should apply, and to what issues it should apply. The majority insisted on a "clear and convincing" showing of "an unalterably closed mind"; the dissent, a preponderant showing of "substantial bias or prejudgment." The majority and dissent each uses the adjective "critical" to describe the type of fact to which its test would apply, but the majority's discussion makes it appear that a "critical" matter must be very specific, one as to which cross-examination must be provided under the Magnuson-Moss Act, while the dissent regards ultimate conclusions and broadly defined social issues as coming within the test's protective reach.

(i). Burden of demonstration. No established principle suggests favoring the majority's "clear and convincing" standard or the dissent's "preponderance." As indicated above ${ }^{188}$ and remarked in the dissent, ${ }^{189}$ the general tendency in recent enactments in other contexts has been to encourage disqualification. Judges may no longer regard themselves as being under a "duty to sit"; mandatory disqualification is to be assessed not by the judge's subjective belief in his ability to be impartial, but by a "reasonable" observer's assessment whether his

185. See note 136 supra.

186. $A N A$, slip op. at 25-29. At the conclusion of this passage he remarks that "[c]ourts have no power to [create] a legislative body of five members whose acts would not be subject to judicial review except to the same extent as Congressional statutes," strongly implying delegation concerns that would equally disable the Congress from creating such a body.

187. Id. at 31

188. See text accompanying notes $68-70$ supra.

189. $A N A$, slip op. at 37 (MacKinnon, J., dissenting in part and concurring in part). 
impartiality is subject to question. That burden is slighter for those challenging judges than either opinion in $A N A$ would require of individuals seeking disqualification in a Magnuson-Moss rulemaking.

Reasons for repudiating so permissive an approach are apparent, and persuasive. In the agency context, the influence of necessity is substantially greater than in federal courts. A court litigant has no cognizable interest in the identity of the presiding judge at the trial, and if one is disqualified another of equal authority ordinarily sits. In an agency, ultimate decision can be made by only one, or, at most, a few individuals who are not interchangeable with available substitutes. Even where decisions are taken by a multimember commission, the removal of one or more commissioners at the behest of individual parties may, by changing the commission's balance, disturb an intended and legitimate "political judgment of the President and the Senate." ${ }^{190}$ Particularly in the context of policy formulation, where permitted policy views will be hard to distinguish from prejudged fact and permitted discussion hard to tell from advocacy, application of a standard as stringent as that applied to judges would, as the majority in $A N A$ feared, frequently "plunge courts into the midst of political battles concerning the proper formulation of administrative policy." 191

This conclusion does not, however, demonstrate either the majority or the dissent to have been correct. All writing judges agreed on the need to avoid encouraging adventitious disqualification claims and to protect agency policymaking. All also agreed on the existence of a claim to impartiality in the particular circumstances of the Magnuson-Moss Act. The balance to be struck between fear of disruption and protection of objectivity was a policy judgment, which the writing judges resolved in policy terms. To the writer, the majority's resolution seems preferable; the integrated character of agency decisionmaking in rulemaking, the centrality of policy and political concerns, and the irreducible difficulty of reliably distinguishing policy from fact in the rulemaking context are persuasive. That, however, does not make the minority wrong-just ill advised from a given perspective. An analyst more highly valuing adversariness in party behavior and objectivity in agency behavior will reach the opposite conclusion.

(ii). What is to be demonstrated? Principle also does not force choice between the majority's "unalterably closed mind" and the dissent's "substantial bias or prejudgment." Both standards respect to some degree the difference between adjudication and policy formation, posing higher barriers to disqualification than does the test applicable in judicial proceedings. Choice between them is equally the product of a balancing process.

The dissent makes two observations about the majority test that may help frame the context for this choice. First, it notes that the "unalterably closed mind" test tolerates subjective self-evaluation in rulemaking, which is plainly repudiated by statute for judicial disqualification; an administrator who responds to a claim of prejudgment that he can consider all sides of the issue will not easily be disqualified on the majority's test. Second, the dissent notes, the major-

190. Id. at 48 (Tamm, J.).

191. Id. 
ity's test is not fairly comparable to that applied to the disqualification of either judges or jurors. Judge or juror disqualification standards would not tolerate opinions on the facts that "would require evidence to remove"; ${ }^{192}$ the majority test does tolerate such opinions as long as they are not ineradicable.

Neither observation demonstrates that the majority is wrong. Even in the judicial context, subjective self-evaluation of possible bias was long accepted as the appropriate mode of analysis; the change to an objective standard has been undertaken only with the increasing incidence of multijudge districts and the ease of modern transportation. The stronger claims of necessity in the agency context and the weaker claims for objectivity in rulemaking readily validate use of a subjective test. Similarly, juror disqualification standards set a reference point usefully defining what (further) requirements could fairly be regarded as excessive, but do not demonstrate the test that must be met for rulemaking.

Indeed, any disqualification test must tolerate at least the degree of prejudgment inherent in the performance of rulemaking responsibilities. The process of formulating a rule could easily lead a rulemaker to the point at which evidence would be required to dislodge his preliminary judgment. The dissent does not seem to propose that such prejudgments be regarded as "substantial." ${ }_{193}$ Something more is required. So long as the dissent's formulation is understood to accept the proposition most strongly stated in Withrow - that combined official functions and any resultant prejudgment are not in themselves sufficient to require disqualification - principle does not force a choice between it and the majority's view.

(iii). As to what facts? It is clearly established-in judicial as well as administrative settings - that only factual, not policy, issues are appropriate for application of disqualification standards; what is such a factual issue in rulemaking, however, is more controversial. In its prior consideration of the problems of hybrid procedures, the Administrative Conference, following established lines of scholarly analysis, has referred to several categories of facts. There is, first, the distinction between "basic facts," the raw material of judgment, and "ultimate facts," the judgment- and policy-laden conclusion of a fact-assessment process, the ultimate matter to be found. Second, there is the distinction, discussed above, ${ }^{194}$ between "adjudicative" and "legislative" facts, between facts of an historical character pertaining to particular individuals and those involving greater elements of judgment or detached from the particular circumstances of a given participant in the proceeding. Finally, within the category of legislative fact, the Conference has distinguished between "specific" and nonspecific fact, the former presenting issues "sufficiently narrow in focus and sufficiently material to the outcome" to make the use of trial-type procedures for their determination "reasonable and useful." ${ }^{195}$ In its recent study of Magnuson-Moss Act

192. Beck v. Washington, 369 U.S. 541,557 (1962), cited in $A N A$, slip op. at $35 \mathrm{n} .11$ (MacKinnon, J., dissenting in part and concurring in part).

193. See text accompanying note 171 supra.

194. See notes $82-84$ and accompanying text supra.

195. See ACUS Recommendation 72-5, 1 C.F.R. § 305.72-5 (1979); H.R. Rep. No. 93-1606, 93d Cong., 2d Sess. 33 (1974) (report on Magnuson-Moss Act), both cited with approval in the majority opinion in $A N A$, slip op. at 23-24. 
rulemaking the Conference commended the development of approaches like those already employed by the Environmental Protection Agency, which limit the use of trial-type procedures to issues of "specific fact." 196

The various categories are hardly airtight and may be excessively scholastic, but they are reasonably well understood and-although subject to the strains suggested earlier ${ }^{197}$ - they identify with reasonable fidelity those circumstances traditionally thought to require the protections of adversary process before an "impartial" decider. Even for judges, "legislative facts" are subject to unregulated judicial notice-while there are strong suggestions that "specific facts" ought not to be so lightly found, the drafters of the Federal Rules of Evidence were unable to write the formula that would produce that result without working mischief to judicial policy formulation. ${ }^{198}$ The $A N A$ majority, accepting these analyses, would find disqualification appropriate only for issues of "adjudicative" or "specific" fact. Indeed, the majority builds on the difficulty of the distinctions as an argument against ready disqualification: because "the factual component of generalized rulemaking cannot be severed from the pure policy aspects of the rule," ${ }^{199}$ a distinctly factual prejudgment cannot readily be distinguished from a prejudgment of policy of which the law should take no heed. The dissent, on the other hand, regards a broad range of prejudgments as possibly "factual" for prejudgment purposes, ignoring these distinctions.

Indeed, it is surprising that the $A N A$ court reached the merits of the disqualification issue rather than reversing on prematurity grounds. The rulemaking in $A N A$ had not yet proceeded to the point of identifying any particular issues as having the materiality, specificity, and controversiality to require on-the-record trial under the Magnuson-Moss Act. The factual assertions which had been made by Chairman Pertschuk were of the most general character-that small children are impressionable, that use of sugared foods contributes to tooth decay, and so forth. These are "legislative" propositions ill suited to adversary processes and falling well outside the range of specific dispute over technological or like matters that can be "decisively resolved by testimony" ${ }^{200}$ and that had led first the D.C. Circuit and then Congress to provide an occasion for hybrid rulemaking. ${ }^{201}$ If apparent prejudgment of such broadly framed issues, much less the "ultimate fact" of need for a rule to remedy these problems, ${ }^{202}$ suffices to estab-

196. Commentary by Conference officials at the time the Magnuson-Moss Act was under consideration had pointed in the same direction. See $A N A$, slip op. at 24,25 , citing communications of Chairman Scalia and Executive Secretary Berg.

197. See text accompanying notes 81-84 supra.

198. See id.

199. $A N A$, slip op. at 20 . 843 (1966).

200. American Airlines, Inc. v. CAB, 359 F.2d 624, 633 (D.C. Cir.), cert denied, 385 U.S.

201. An FTC administrative law judge has recommended in the continuation of the $A N A$ proceeding that the extent to which children can distinguish between commercials and programs "to the point that they comprehend the selling purpose of television advertising aimed at children" be made one of the "disputed issues" for oral hearing in the proceeding. That recommendation may, of course, be in error or embody a political or litigation-avoidance judgment, as much as a judgment that this is a matter best suited for resolution by adversary trial.

202. $A N A$, slip op. at 37 (MacKinnon, J., dissenting in part and concurring in part). 
lish disqualification, policymaking will indeed be impinged upon-both by the occasions given for litigation and by the impact of permitting a collateral issue to interfere with the rulemaking process.

The working hypothesis of the Conference's recent work, and the predominant body of contemporary administrative law scholarship, is that the "specific fact" distinction can be made. A characteristic of "specific facts" is that they do not require judgment, prediction, or policy orientation for determination. Although not "adjudicative facts" in the strictest sense-involving neither specific individuals nor historic circumstances - specific facts by hypothesis share the characteristics of concreteness and provability that make trial-type procedures superior for their determination. Determining the ductile strength of a given steel alloy differs from making a judgment about the anticompetitive impact of joint ownership of television stations and newspapers, in just this way. Facts about ductility can be developed through evidentiary hearings, and are severable from policy issues. To this extent the majority appears to be wrong. If a disqualification standard would be limited in its application to "specific facts," narrowly defined, policymaking functions would not be threatened. With careful definition of "fact" and "policy" no established principle favors the majority's formulation of a disqualification standard over the dissent's. Only the scope of application threatens effective policymaking. The implication of this analysis is, of course, that whether disqualifying prejudgment of specific facts in issue exists cannot be determined until those facts and the issues respecting them have been defined. ${ }^{203}$

Judge MacKinnon, however, was concerned with prejudgments not of specific fact, but "of the ultimate fact involved-the "evil' of such advertising." 204 He objected not to Chairman Pertschuk's policy judgment that rules controlling advertisement of sugared cereals on children's television programming might be appropriate, but to his behavior as a "loud advocate[] . . . haranguing the public," his "vigorous and consistent advocacy." 205 Taking these observations at face value, one can suggest that the dissenting concern here is not with factual prejudgment but with decorum and the collection of considerations generally described under the heading "animus." The judge's perception was that Chairman Pertschuk set out to achieve a given result. What the underlying facts might be is less important than his apparent indifference to them. It may even be that his inner conviction is regarded as less important than his public behavior-behavior likely to engender disrespect for the agency's actions. ${ }^{206}$

203. See note 201 supra.

204. $A N A$, slip op. at 37.

205. Id. at 31 . (1979).

206. See Note, Regulator Disqualification from Rulemaking Proceedings, 57 Tex. L. Rev. 1193 


\section{B. "Animus" or Partisan Zeal}

The appearance of having taken sides with or against one of the participants is a well-established ground for judicial disqualification. ${ }^{207}$ Even if a judge has learned all he knows within the four corners of the record, he may be disqualified if his behavior signals a loss of the necessary capacity to remain objective in assessing new material. Yet it is the business of judges to reach judgments on the basis of the material that unfolds before them, and it is inevitable that these judgments will form as the trial proceeds, that their shape will become apparent (if not immalleable) over time. A rule permitting ready disqualification of judges who appeared to be drawing conclusions from the matter properly before them would provide too easy a shield for the avoidance of deserved defeat; there is also the risk, borne out on occasion, that parties fearing defeat would be tempted to provoke the judge into a disqualifying show of judgment. For such reasons, courts discussing this aspect of judicial disqualification express no concern for the presence or strength of a judge's inner conviction absent evidence of disqualifying sources of information; public conduct is required. And such conduct, one senses, is viewed very much in context-against the backdrop formed by the behavior of the complaining party and the reviewing courts' appreciation of the normal pressures and tendencies of extended, hotly contested litigation. Only behavior reflecting irrational attachments or leanings appears to provoke appellate censure. Courts seek an indication of judicial attitude toward the parties ${ }^{208}$ not rationally explainable in terms of the events disclosed of record. The risks of party manipulation otherwise are too high. The result is a very low apparent rate of disqualification relative to the number of occasions on which it might be sought on these grounds.

Disqualification for animus in agency rulemaking would be further complicated, particularly at the agency top, by the characteristics setting rulemaking apart from adjudication: the pre-notice involvement of agency heads in identifying the occasion for a rule and developing a proposal; the need for and appropriateness of their commitment to implement particular policies, commitments that may have sparked their appointment; and the need for and appropriateness of discussing evolving agency policy within and without the government, both to provoke sharing of information and views and to encourage voluntary compliance and political support. All of these activities are likely to produce outward indications of leaning and commitment. Consequently, to permit disqualification claims is to risk engendering litigation which-even if it does not often succeed-could chill important aspects of agency public life. The result would be to reduce the political controls over agencies, valid and valued controls that do not operate against judges or those acting in a judicial capacity. The more

207. See note 76 supra.

208. Attitude toward the parties, although not always readily distinguishable from prejudgment as to disputed fact, is at the core in this context. A disposition to disbelieve the witnesses or distrust the motives or good faith of a party is the attitude characterizing judicial "animus" cases. 
importance one attaches to these political processes and controls, the more hazardous is an animus ground for disqualification. ${ }^{209}$

It is on the question of animus, moreover, that the conflict of interests analysis undertaken above ${ }^{210}$ is most instructive. Even formal prior association with a participant in rulemaking does not require government executives and policymakers to step aside. Yet these associations plainly signal party affiliations. Although, increasingly, cooling-off periods are regarded as appropriate for those who come to government from employment in which they would have had a financial stake in the outcome of a proceeding pending at the time of their employment and in which they had participated, this judgment may exclude general rulemaking - another indication that likely commitment is not regarded as important. Most important here, cooling-off periods prompted by associations with nonfinancial interests are currently observed chiefly as a voluntary matter and if adopted for the future (a step for which reasonable arguments can be made) will inevitably be hedged with substantial restrictions. The reasons for caution in extending conflict of interests analysis in this way reflect recognition of the legitimacy of strong policy views as an element of the appointive process and subsequent governmental action.

Whether rules permitting disqualification for demonstrated strength of feeling toward the subject of a rulemaking ${ }^{211}$ would inhibit reasonable public discussion is, as an empirical question, not readily answered. Analogous concerns were felt in connection with enactment of the Freedom of Information ${ }^{212}$ and Government in the Sunshine Acts; ${ }^{213}$ the extent to which those measures have inhibited candid exchange of views has not been measured, nor can it easily be calculated whether, even assuming such impacts, the acts have conferred a net public benefit. To the writer, however, the argument that inhibition will occur seems the stronger. Pillsbury Co.v. FTC ${ }^{214}$ has helped shape the character of

209. The dispute between majority and minority in $A N A$ is perhaps best understood in these terms. The majority stresses the political functions of rulemakers-functions independent of procedure as such. The dissent underscores the judicial characteristics of the procedures employed at one stage of the rulemaking, and in arguing that Chairman Pertschuk must be disqualified stresses his partisanship, his political ends in view, and the political settings in which he sought to build support for the soon-to-be-proposed rule. It is precisely the element of zeal, of attitude not toward fact as such but the supposed motives of the cereal manufacturers/advertisers and the outcome of the proceeding, that draws Judge MacKinnon's sharpest fire. See, e.g., slip op. at 31.

210. See text accompanying notes 48-51 supra.

211. One might not reach the same conclusions where focused personal hostility toward a particular participant could be shown - an improbable but possible state of affairs in rulemaking. In this context, the inquiry might be whether the affairs of the particular participant are so near the heart of the rulemaking as to suggest the possibility of a vendetta; or whether the participant's affairs are of peripheral concern or any hostility is expressed chiefly in its own behavior. See note 76 and accompanying text supra. But for the unusual case in which the possibility of vendetta might be made to appear, the dissent's test is well within reach of both general expectations and probable congressional outlook; it does not appear overly threatening to ordinary rulemaking processes or relationships.

212. Pub. L. No. 93-502, 88 Stat. 1561 (1974) (codified at 5 U.S.C. § 552 (1976))

213. Pub. L. No. 94-409, 90 Stat. 1241 (1976) (codified at 5 U.S.C. § 552b (1976)).

214. See note 123 and accompanying text supra. 
congressional oversight of agency adjudication; Texaco and Cinderella ${ }^{215}$ produce careful internal reviews of commissioner speeches against current dockets. Similar impacts on speechmaking and congressional appearances seem likely to occur in this context. It does not follow that those impacts are objectionable; that the gain in agency independence or public perceptions of fairness and "objectivity" do not counterbalance any losses. It bears repeating in making any such assessment, however, that in on-the-record adjudication both the values and the practical attainability of objectivity in the decisionmaker are at the core and political controls are regarded as inappropriate; for rulemaking, political controls are workable and generally accepted. In the current dispute over advertising directed to children, for example, most think it appropriate for Congress to discuss and act on the question of whether FTC competence extends to "unfair" as well as "deceptive" commercial practice even while that issue is pending at the FTC. Insulating FTC commissioners and staff from political discussions respecting such questions has much larger consequences than insulating them from political discussions of whether Pillsbury Co. has engaged in particular anticompetitive conduct.

Political controls also seem likely to serve as significant nonjudicial correctives for indecorous behavior. The recent legislative debates over FTC authority were fueled in no small measure by Chairman Pertschuk's public activism, including specifically his speeches on advertising directed to children. Seeming a partisan has real and immediate political impacts generally well understood by Washington regulators, impacts tending to promote judiciousness in expression but not threatening collateral litigation or the defeat of otherwise acceptable policy initiatives years after the agency's decision. The existence of the political controls, wholly inappropriate for judges or adjudication, both diminishes any need for judicial controls and signals their undesirability.

A rule permitting disqualification for apparent strength of feeling toward the subject of a rulemaking, then, is inappropriate in the absence of rather direct indications of congressional provision for such a rule. The result is too unusual, in terms of general expectations or Congress's own behavior, to make that inference easily. In particular, provision for hybrid or modified rulemaking procedures does not seem sufficient support. It is reasonable to infer from such a provision the judgment that a measure of objectivity is required as to the "specific facts" that are sharply in dispute. That flows more or less directly from the determination that trial-type procedures are appropriate for the assessment of these facts. It requires a further step to infer the judgment that the regulator may not have political commitments to act or enthusiasm for acting in the policy arena on which those facts bear. And that further step, if taken, will carry disqualification procedures into a setting in which extreme caution has been taken even as to judges - in recognition both of the natural consequences of decisionmaking in any complex matter, and of the dangers of party manipulation. For these reasons the majority test—or none at all-seems clearly preferable.

215. See notes 112-20 and accompanying text supra. 
One may test these conclusions against Assistant Secretary Bingham's passionate speech to the Steelworkers. ${ }^{216}$ Here, unlike $A N A$, the question of disqualification was raised only after the rulemaking was complete, on the basis of a speech given at a time when, inevitably, the intellectual process of reaching judgment would have been complete. The remarks she made indicate strong commitments on a variety of matters, ranging from the political to the technical. Undoubtedly, too, Dr. Bingham brought from her role in private life as a specialist in workplace health hazards strongly held views about the needs for worker safety; she had been selected precisely because of her background and attitude.

The largest element of the objections, as with Chairman Pertschuk, appears to have been to Dr. Bingham's choice of forum and manner. The speech was openly political, given as the most hotly objected of Chairman Pertschuk's remarks had been, to a constituency on the opposite side of the issue. From an industrialist's perspective, it must seem very raw, and would equally have seemed so had the speech been given after adoption of the standard. But at this level of generality, raw as it is, no requirement of detachment can be inferred from the statute or otherwise. In describing her trips through "the palace guard," Dr. Bingham described existing political processes of control that are an inherent part of rulemaking as currently understood; repudiation of those processes, if warranted, should not be accomplished through the back door of a disqualification standard. Solicitation of political support is equally part of an Assistant Secretary's job as now understood. Remarks about inflationary impact or attitudes toward the willingness of society to bear the added costs of worker protection, however strongly felt or misguided, are far too general to suggest prejudgment; they reflect the sorts of broad political attitudes that all experienced persons bring to public office.

Dr. Bingham's remarks about medical removal protection similarly fail to suggest prejudgments of fact. "Medical removal protection" is a regulatory measure requiring companies to maintain workers removed from a work environment for health reasons at their former rate of pay. OSHA's authority to impose such a measure and the need for it were hotly contested, but neither issue suggests disputes of fact as to which cross-examination or the ability to decide solely on the basis of a record are requisite. Even if, as appears, Dr. Bingham came to office with unshakeable views on these matters, that would be no occasion to disqualify. Whether she was wrong on the question of authority will of course be resolved by the courts; the disposition to impose a certain measure within her authority, if known, would be a valid reason only for making or withholding her appointment.

In short, the speech-fiery as it was-appears not to have reflected prejudgments on particular contested issues of specific fact. Its fire may well have cast discredit on the result in some quarters, contributed to a sense of unfairness or social malaise unfortunate in a society that depends largely on good will and voluntary compliance for adherence to law. The proper correctives, however, are

216. See note 13 supra. 
political, not judicial; a judicial corrective would of necessity extend requirements of objectivity beyond their reach even in analogous judicial circumstances and correspondingly impair the necessary political controls of the regulatory system. $^{217}$

\section{CONCLUSION}

This analysis produces some reasonably firm conclusions and leaves other matters to political judgment.

Taking first the question of conflict of interests, disqualification in rulemaking is plainly appropriate in those circumstances, largely defined by federal statute, that involve present significant risks of present financial self-dealing. Mandatory disqualification for conflict of interest seems equally inappropriate on the ground merely of violation of the government's general precepts of ethical employee behavior. Between these poles lie the questions of whether adoption of a rule precluding investments only in companies principally regulated by an agency is sufficient protection against disqualifying self-dealing; and whether conflicts arising out of prior employment or present nonfinancial interests should be disqualifying. Answers to these questions derive from experience and world view, not logic; but extension of conflict of interest enforcement in each of these areas would reflect current trends. The indirect impacts of rulemaking on financial holdings can be substantial and so, in a society concerned to avoid selfdealing, disabling. "Cooling off periods," in increasing use, reflect heightened awareness that changes in associations do not produce sharp and immediate changes in loyalty or prior perspective. A legal system recognizing that nonfinancial interests can be substantial enough to sustain a claim to participate or sue seems also likely to recognize that they can be productive of disabling conflict.

Disqualification for bias or prejudgment in rulemaking had not been an established remedy prior to the decisions in $A N A$, and is not provided for in agency rules or practice. Federal agencies generally state a commitment to openmindedness on the part of decisionmakers, but rely on voluntary recusal. Analytically, the proposition that disqualification may be constitutionally required for fairness is very weak. Any such requirement is inferable only from particular statutory requirements of procedures suggestive of a need for objectivity. Nothing in APA section 553 supports such an inference, but an inference that protected objectivity in some measure is required could be drawn from statutes requiring use of trial-type procedures to a greater or lesser degree.

How much objectivity, how severe the disqualification test, is the more difficult question. A proper test must not interfere with necessary elements of

217. The D.C. Circuit decided the United Steelworkers case on Aug. 15, 1980, upholding the rule against this challenge. United Steelworkers of America v. Marshall, No. 79-1048 (D.C. Cir. Aug. 15, 1980). The court admonished Dr. Bingham for "making statements so susceptible of an inference of bias, especially statements to a group so passionately involved." Slip op. at 18. But it found no commentary on specific factual issues that could warrant application of the ANA test. 
policymaking activity; neither acts nor beliefs producing the decision to initiate a rule, the formulation of a proposal, or the conduct of policy discussions with Congress, the regulated industry, or the public should be regarded as disqualifying. A further proposition, mirroring the rules applicable to judicial disqualification, is that only prejudgment as to "fact" is even arguably disqualifying. Since the requirement of objectivity derives from statutory inference, the range of disqualification is appropriately limited to those facts subject to that inference-in the case of hybrid rulemaking procedures, the specific facts as to which full adversary procedures may be required.

Within the boundaries thus suggested, principle suggests no basis for choosing between a test of disqualification requiring a "clear and convincing" showing of "an unalterably closed mind" and one turning upon a preponderant showing of "substantial bias or prejudgment." The two tests reflect differing emphases, one preferring noninterference in an inevitably political process and the other, assurance of objectivity where a requirement of objectivity may fairly be inferred. But both tests place an appropriately greater burden of demonstration on the party seeking disqualification in rulemaking than would have to be met in adjudication. Within the suggested limits, neither is demonstrably wrong.

If one moves from the specific facts that may be shown in any case of hybrid rulemaking to warrant full trial consideration to the broader ranges of "legislative" or "ultimate" fact, the question shifts from factual prejudgment or bias to animus or partisan zealotry. While decorum in the conduct of public business is greatly to be sought, the hazards of seeking to enforce it in a rulemaking context, avowedly political, are even greater than they would be in the context of judicial activity. In this setting, absent evident personal vendetta, one might well prefer to leave correction of indecorous behavior entirely to the political realm-to congressional reaction, loss of public acceptance, and collegial censure. If disqualification is to be entertained at all by the courts, the barriers must be set extremely high.

\section{APPENDIX}

At its June 6, 1980, plenary session, the Administrative Conference adopted the following recommendations based on the preceding report:

RECOMMENDATION 80-4

\section{Decisional Officials' Participation in Rulemaking Proceedings ${ }^{218}$}

\section{A. Procedures}

1. Each rulemaking agency should promulgate procedures by means of which persons who desire to participate in a rulemaking proceeding (or who may

218. Administrative Conference of the United States, Recommendations, 45 Fed. Reg. 46771, 46776 (1980) (to be codified in I C.F.R. $\$ 305.80-4$ ). 
be affected by its outcome) can challenge the suitability of participation by particular decisional personnel in that proceeding. The procedures should identify the factors that bear on suitability and should indicate the appropriate time, place, and means of making challenges, along with an indication of opportunity for intra-agency review if one be available.

2. The procedures should also make plain that a decisional official, whether or not challenged, may voluntarily abstain from participating in a particular proceeding.

\section{B. Conflict of Interests}

1. A decisional official whose financial interests or those of whose immediate family may be distinctively favored by choices to be made in a particular rulemaking proceeding should voluntarily abstain (or be required by the agency to abstain) from participation in that proceeding, subject to publicly stated and applied agency exceptions for de minimis holdings.

2. New agency officials should be subjected to "cooling off" periods of variable duration, during which their participation in a rulemaking proceeding would presumably be inappropriate if

(i) the proceeding specifically affects the financial interests of an immediately prior employer or client; or

(ii) the official's immediately prior employer or client is a participant in the proceeding; or

(iii) the official has participated in the proceeding before becoming a public employee.

An agency's application of a "cooling off" requirement should not, however, reflect absolutes. It should take into account the following factors, singly or in combination:

(a) the extent of the official's participation in a prior private capacity in the pending rulemaking proceeding;

(b) the elapse of time between the prior involvement and the official's present activity as a public employee;

(c) the nature and magnitude of the rulemaking's possible impact on the interests of the prior employer;

(d) the generality or specificity of the rulemaking's scope;

(e) the extent of the prior employer's participation;

(f) applicable professional standards;

(g) Senatorial consideration, during the confirmation process, of the official's prior relationships and activities.

3. An official's non-financial interests, associations, or activities (whether or not related to past employment) may in some instances suggest the desirability of recusal or, if need be, a direction to the official to abstain from participating in a particular proceeding. If the official's appointment has been confirmed by the Senate with knowledge of the appointee's past interests and activities, a required cooling off period would ordinarily be inappropriate. As to officials of lesser prominence, however, agencies may suitably utilize in respect of nonfinancial interests the procedures sketched above, related to financial conflict of 
interests or to cooling off periods. The question of precluding participation should arise only when an identifiable interest is significant in relation to the proceeding and is likely to be substantially affected by its outcome. Mere membership in an association would not ordinarily be a ground for disqualification or recusal.

4. Finally, agency conflict of interests rules should make emphatically plain that they are in aid of the agency's self-management; that they are measures in furtherance of its own quality control rather than in amplification of judicial control; and that they are agency declarations for guidance of its own staff concerning decorum. An agency that is insensitive or lax in fulfilling its declared expectations will no doubt be of concern to the Congress or to the Executive, but an agency's heightened attentiveness to the qualities of decisional personnel should plainly not expand the occasions for or the scope of review of rulemaking proceedings.

\section{Prejudgment of Fact}

1. Disqualification for prejudgment in rulemaking should be limited to prejudgments of particular "adjudicative", or "specific" facts, where it may be inferred from the particular statutory framework, agency procedural choices, or other special circumstances that the agency's determination of those facts is to be based on the evidentiary record developed in the proceeding. Cause for disqualification can appropriately be decided by the agency only after it is established in the proceeding that such facts will be materially at issue in the proceeding. Such disqualification is inappropriate for factual judgments that are the consequence of earlier stages of the proceeding, of for prejudgments of policy.

2. To avoid undue interference with the legislative, policy-making aspect of the rulemaking process and other agency functions, disqualification for prejudgment of fact should be considered by the agency only after it has determined that critical "adjudicative" of "specific" facts require resolution on the evidentiary record developed in the proceeding, and should require at least a preponderant showing that an agency member or decisional employee has a closed mind regarding those facts.

\section{Decorum and Expression of Views}

A rulemaking proceeding should be conducted with decorum and respect for the interests of all concerned. Agency officials should therefore conscientiously avoid intemperate expression or other behavior suggestive of an irrevocable commitment to a predetermined outcome of the proceeding. This does not mean, however, that agency officials may not express factual judgments based on previous experience or on information received during a proceeding; nor does it suggest that officials may not act upon or voice opinions concerning underlying issues of policy. Expressing those opinions in interchanges with committees of the Congress, other administrative bodies, the public, and regulated groups is a desirable normality of administration, rather than an abnormality to be shunned, and is not a basis on which exclusion from a proceeding may appropriately be suggested. 